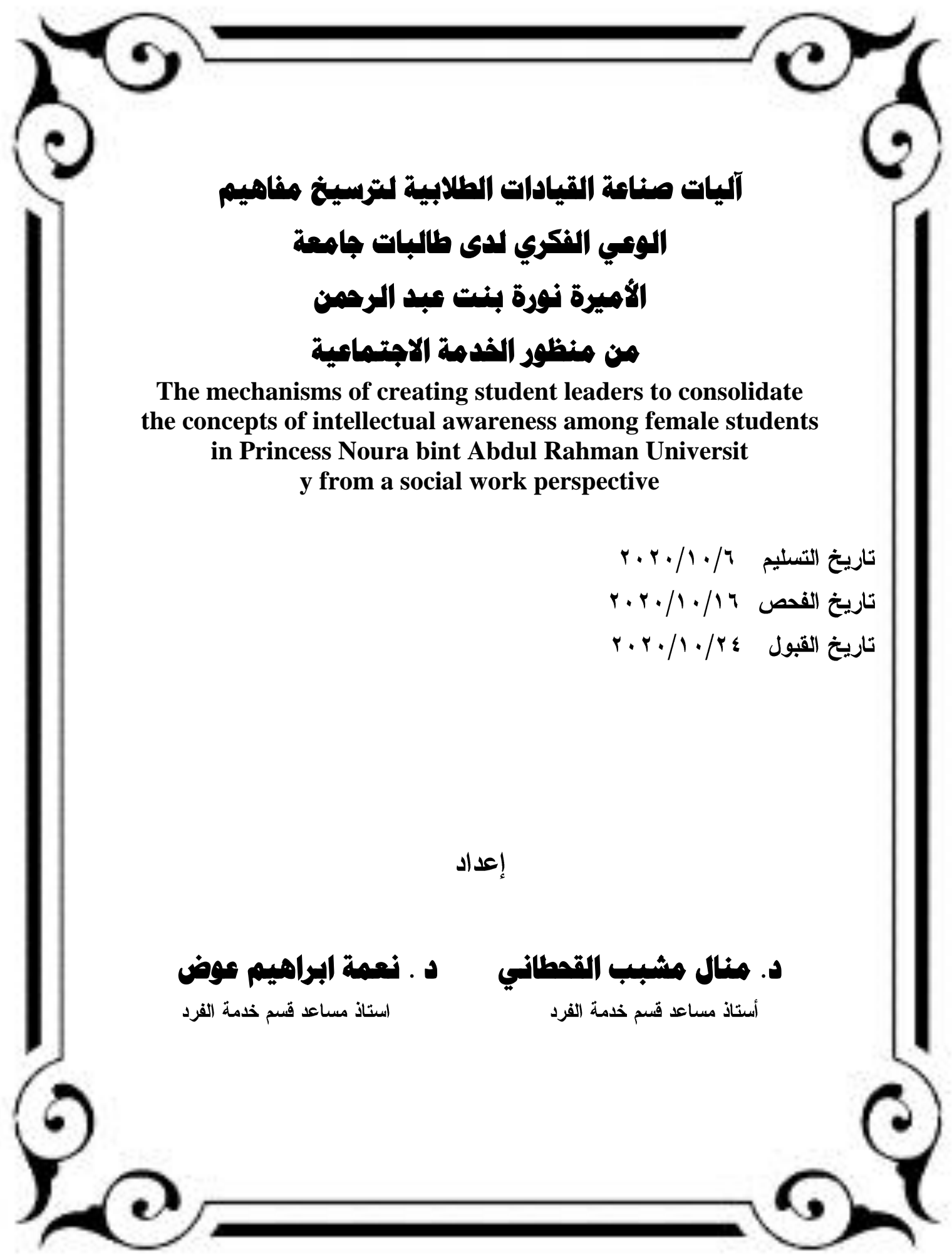



آليات صناعة القيادات الطلابية لترسيخ مفاهيم الوعي الفكري لاى طالبات جامعة الأميرة نورة بنت عبد الرحمن من منظور الخدمة الاجتماعية

\section{اعداد وتنفيد}

\section{د. نممة ابراهيسم عوضن}

استاذ مساعد قسم خدمة الفرد

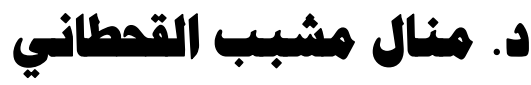

أستاذ مساعد قسم خدمة الفرد

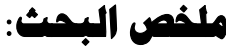

هدفت الاراسة بشكل عام إلى التوصل إلى تصور مقترح من منظور الخدمة الاجتماعية يساعد في ترسيخ

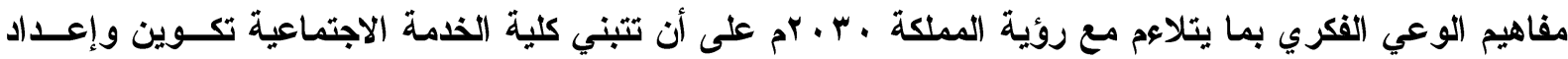
قيادات وسط الطالبات و التي من المتوقع مساهتهن في ترسيخ الوعي الفكري لاى الطالبات ، وفي سبيل تحقيق ذلكي

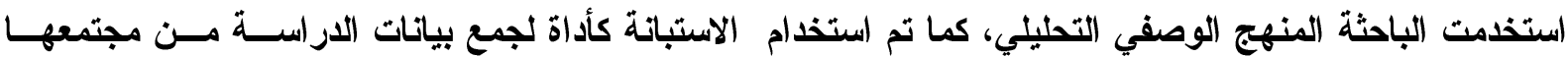

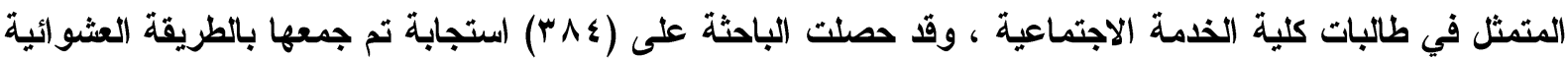

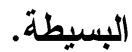

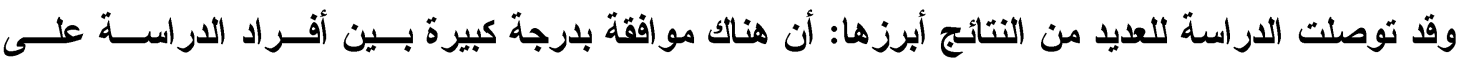

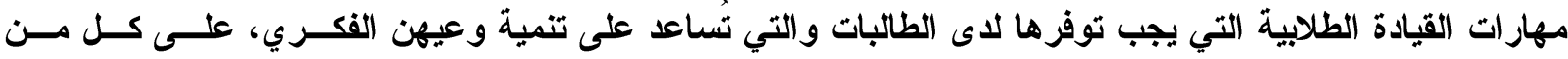

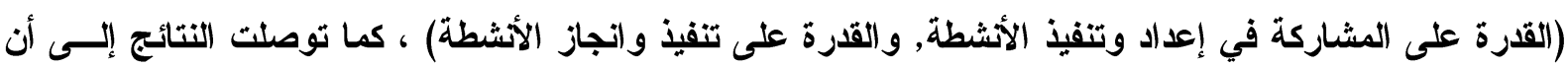

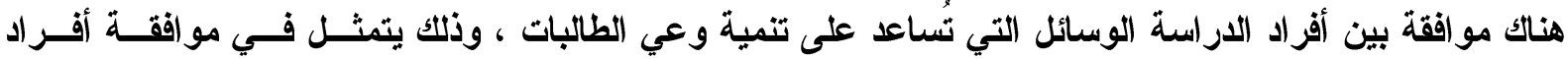

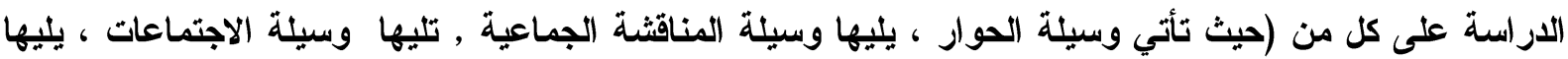

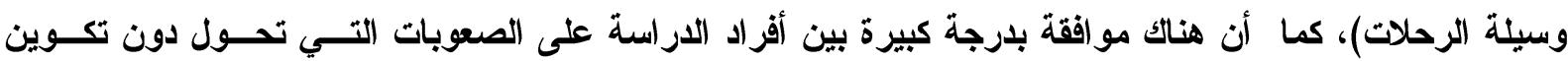
وصناعة قيادات طلابية بالكلية، ويتضح ذلك من خلال (ضعف حماس الطالبات بسبب الضغوط الأكاديمية) واخيراً فقد

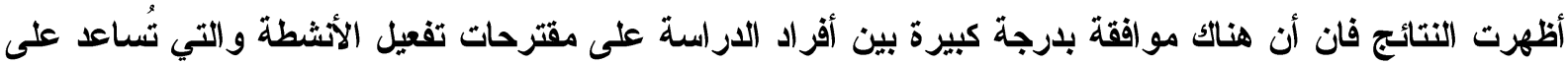
تنمية الوعي لاى الطالبات من خلال (توفير برامج متنوعة تساعد في التوعية, وفتح قنوات اتصال بـين الطالبـات

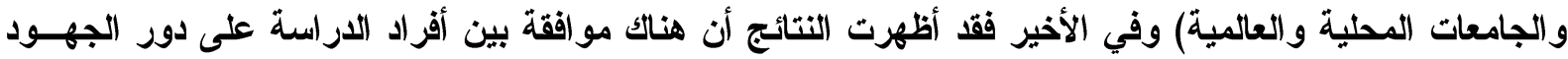

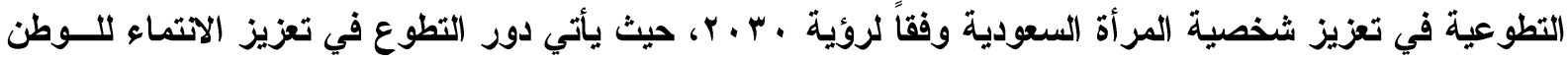

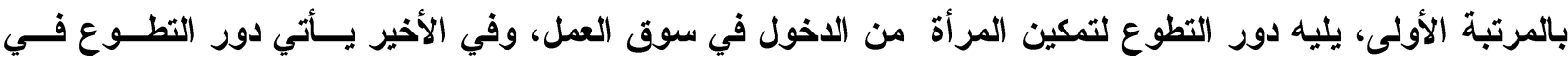
ترسيخ قيم التسامح والوسطية كأفل أدوار الجهود التطوعية في بمتوسط حسابي تعزيز شخصية المــرأة الســودية

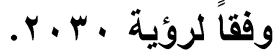

الكامهات الافتامية :آليات - صناعة القيادات -القيادات الطلابية - ترسبخ - مفاهيم الوعي الفكري. 


\section{Abstract}

In general, the study aimed to arrive at a proposed vision from the perspective of social work that helps consolidate the concepts of intellectual awareness in line with the vision of the Kingdom 2030 AD, provided that the College of Social work adopts the formation and preparation of leaders among students who are expected to contribute to the consolidation of intellectual awareness among students, and in order to achieve The researcher used the descriptive and analytical method, and the questionnaire was used as a tool to collect study data from her community of students of the College of Social Work, and the researcher got (384) responses that were collected by a simple random method.

The study found many results, the most prominent of which is: that there is broad agreement among the study members on the student leadership skills that must be available among the students and which help to develop their intellectual awareness, on both (the ability to participate in the preparation and implementation of activities, and the ability to implement and complete the activities) The results also found that there is agreement among the study members and the means that help in developing the awareness of the students, which is represented in the consent of the study members to each of (where the method of dialogue comes, followed by the method of group discussion, followed by the means of meetings, followed by the means of excursions). There is, to a large degree, agreement among the study members about the difficulties that prevent the formation and making of student leaders in the college. This is evidenced by (the students 'lack of enthusiasm due to academic pressures). Finally, the results showed that there is broad agreement among the study members for proposals to activate activities that help to develop awareness among students through (providing various programs that help in awareness, and opening communication channels between Finally, the results showed that there is agreement among the study members on the role of volunteer efforts in enhancing the personality of Saudi women in accordance with Vision 2030, where the role of volunteering in promoting belonging to the homeland comes first, followed by the role of volunteering to enable women to enter the labor market And in the end, the role of volunteering in consolidating the values of tolerance and moderation is the least of the roles of volunteer efforts in an arithmetic average, enhancing the personality of Saudi women according to Vision 2030.

key words : Mechanisms - Leadership Industry - Student Leadership Establishing - the concepts of intellectual awareness. 


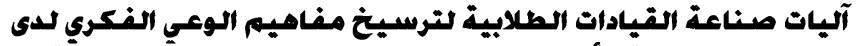

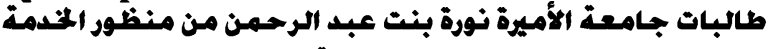
الاجتماعية

د. منال مشـبـ القحطبني - د. نعمة ابراهيم عوض

\section{مشكلة الدراسة}

نجد أن المؤسسـات التربوية تهـتـم بإعــداد وتأهيـل

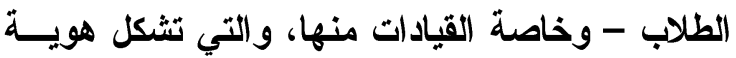
المجتمع وصياغة توجهات أفراده، ولذلك تعمل تلــــ المؤسسات على مناقشة وإعداد تلـــــ القيــادات وأن تؤسس لتربية قائمة على القيم، حيث يعتبــر التعـــيم

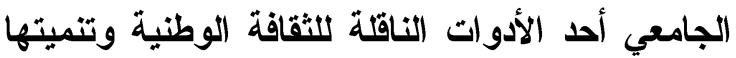
وتطويرها والمحافظة عليها بالقدر الأي يكون له دور حاسم في تثكيل الثخصية الوطنية لاى الطلاب، وهذا يتطلب أن يكون الطلاب على درجة من الوعي الفكري

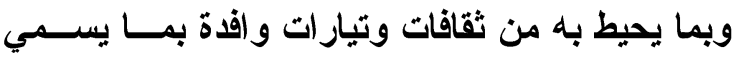
بالتغزيب الثقافي وإضعاف الهويــة الثقافيـة بســبـ الاتفتاح المعلوماتي و التقليا.

ونسبة لما يتمتع به الثباب من الطلاب مسن طاقــات

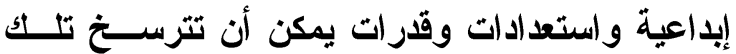
القيم التي تحفظ إلى المجتمعات هويتها وقيمها، مثـلـل قيم المسئولية الاجتماعية، قيم المواطنـــة والاتتــــاء للوطن وقيم المشاركة المجتمعية على سبيل المثـال، ويتم ذلك من خلا خططها الإســتراتيجية وروئيتهـا

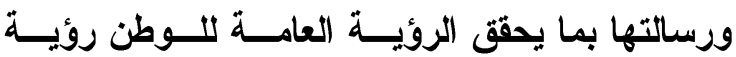

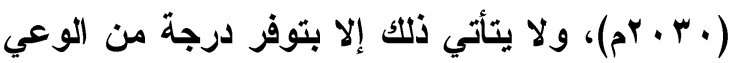

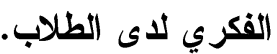

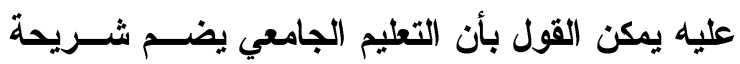

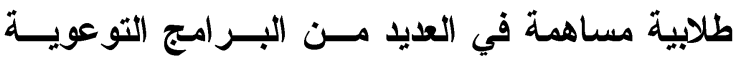
والأنشطة اللاصفية سواء كان ذلك تحت مظلة الكيان

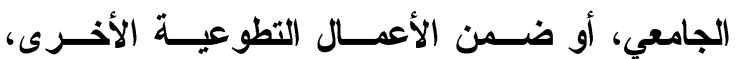
فالجامعات ومنسوبوها من الطلاب وأعضـــاء هيأســة التدريس هم منابر فكرية هامةة، والطلاب في الجامعات

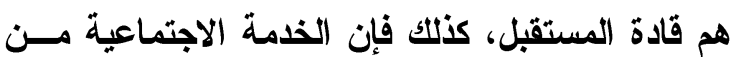
خلال مناهجها التعليمية تعمل علــى إعـــاد وتتميــة

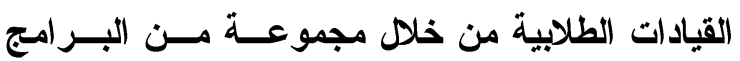

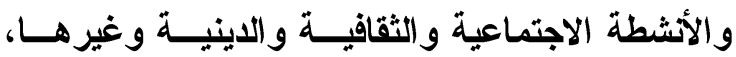

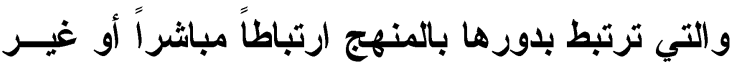

القيادة ظاهرة تبدو في مختلف المجالات التربوية

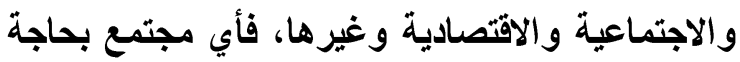

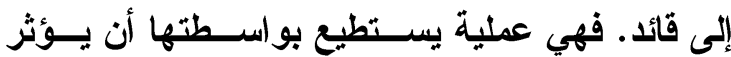

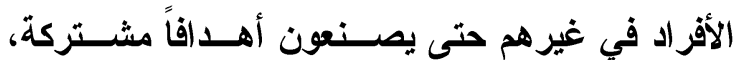

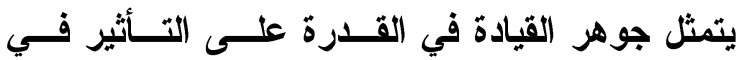
الآخرين والتي بدورها لا تتوافر إلا بتــوفر مقومـــات

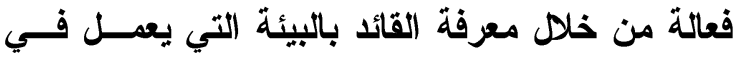

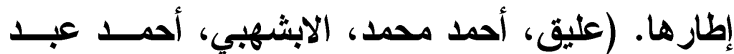

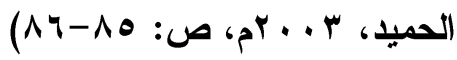

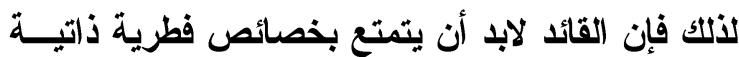
كالإبـاع و التفكير والقدرة على التصــور والتخطـبط، بالإضافة إلى تـــوفر مهــار ات اجتماعيــة كالعلاقَــات والاتصال و التحفيز في استتفار القدرات، إلــى جانــب

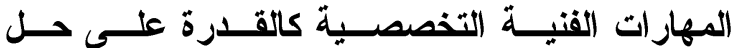
المشكلات واتخاذ القرارات.(المرجــع الســابق، ص:

ويرى إبراهيم الفقي أن غــزارة المعرفــة، الثقافــة،

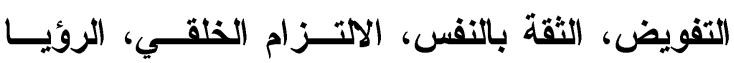

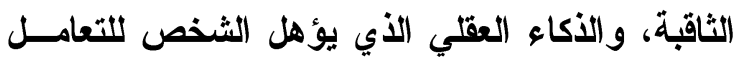

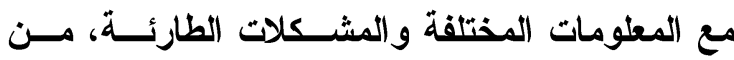

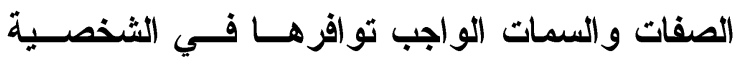

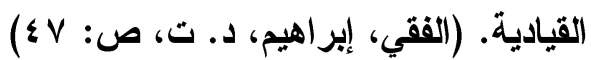

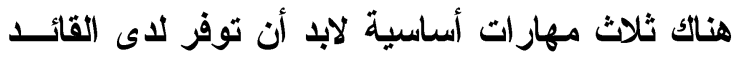

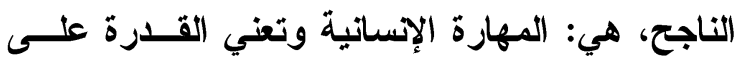

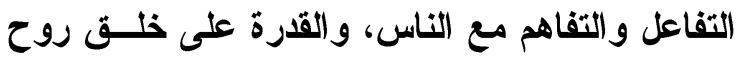
العمل، والمهارة الفنية (المهنية) وهي المعرفة والفهم ولنماني لنوع العمل الأي يؤديه والأي يختلف من مجال إلــى ولى آخر، ثم المهارة الفكرية، وهي القدرة علــى تصـــور

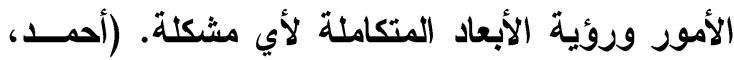

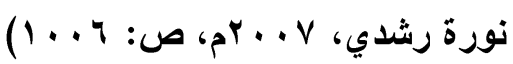




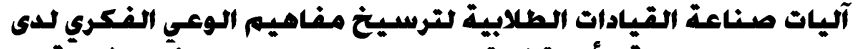

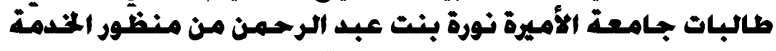
الاجتماعية

د. منال مشـبـ القحطبني - د. نعمة البراهيم عوض

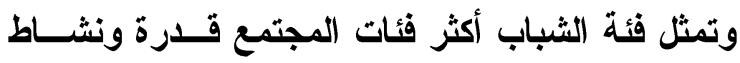

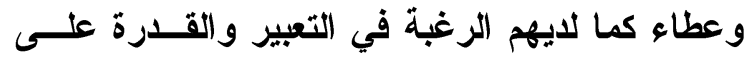
الإبداع والابتكار (عبيد، حي مرسي، 991 ام، ص:

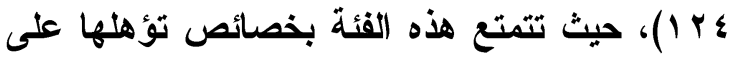

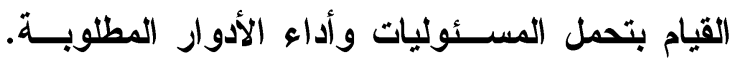

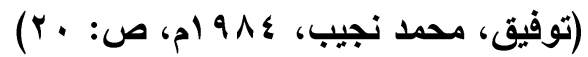
ويتوقف مستقبل التغير في كافة المجتمعات على الدور الأي يقوم به الثباب ويرتبط بمدى وعيـه و إدراكــهـ

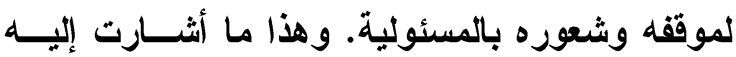

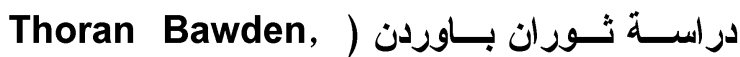
2005) والتي أكد من خلالها أن وعي الثباب بقضايا عصره ومشكلاته هو الوسيلة الرئيسة التي تمكنه من ون تحقيق أهدافه المرجوة. (Bawden,2005,p.34) ولقد تزايد الاهتمام بشباب الجامعات باعتبار هم قــادة

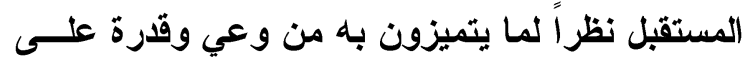

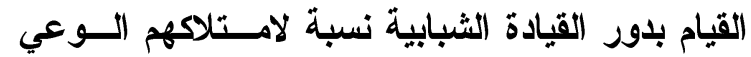

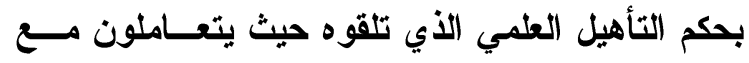
مختلف القضايا بوعي ومسئولية. (منقريوس، نصيف

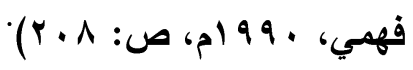

فالجامعات هي منظمة ينتــي إليها الثــباب يتلقــون

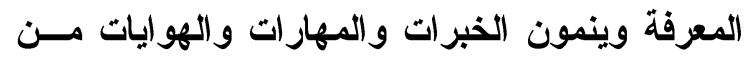

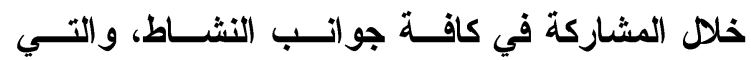

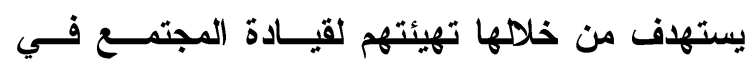
المستقبل، وذلك بإتاحة الفرصــة أمسامهم ليثــاركوا بأنفسهم في صناعة القرارات التي تتصـلـل بحيـاتهم

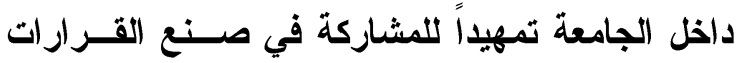

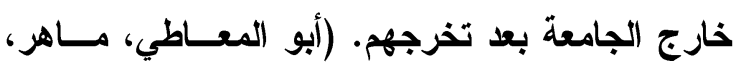
( 999

ويعتبر هدف رعاية الثباب في الجامعات هو تنميــة

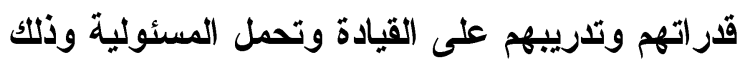

عن طريق برامج ومشروعات الأشطة المختلفة. وأثثارت دراسة عاطف خليفة محمد (99v ام) إلى أن مشاركة الطلاب في الأشطة هي لتنميــة المســئولية

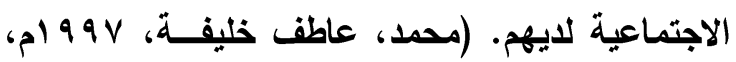

المجلة العلمية للخدمة الاجتماعية

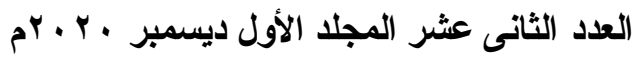

مباشر، وذلك وفق خطط مرتبطــة بسياســـة التعلــيم وسياسة الاولة.

ومن هذا المنطلق نبعت مشكلة البحث الحالية، وهـي

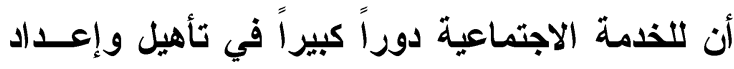

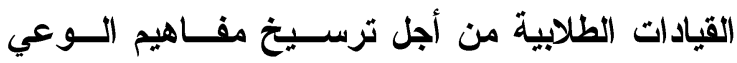

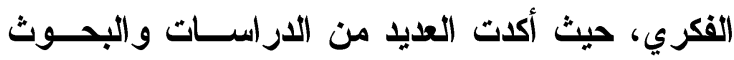
الاور الأي يقوم به الأخصائي الاجتماعي وفرق العمل

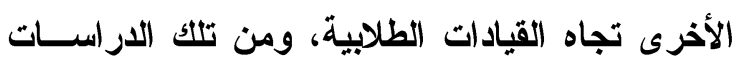
الاراسة التي أكلات نتائجها أن هنالكك علاقة بين قيـام

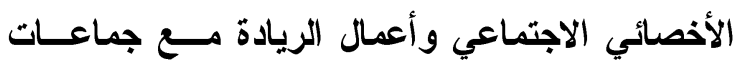

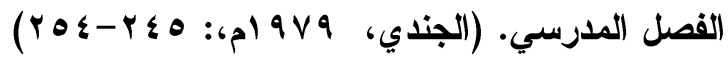
وأكلات دراسة الثافعي العلاقة بين استخدام أســاليب

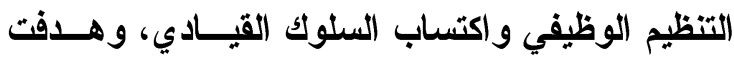
الاراسة إلى إكساب الثباب مجموعة من المهــارات

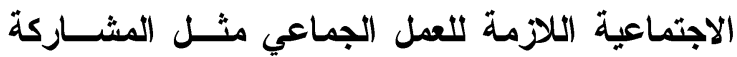

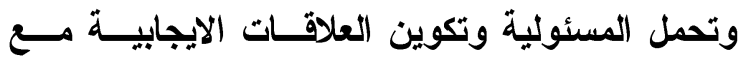

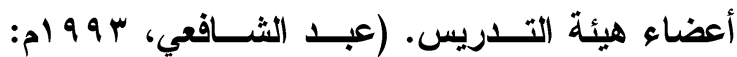
كما أكلات الدراسة على أن تحديا محتويات وبــرامج وأنشطة الثباب تنمــي فـي الثــباب روح القبــادة الرشيدة وخصائص المواطنــة الصــالحة ومهــار ات ات

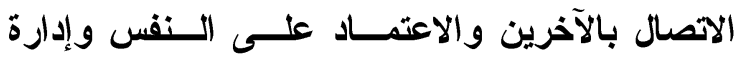

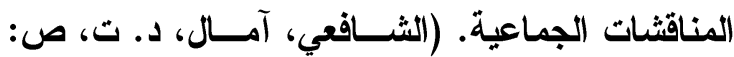

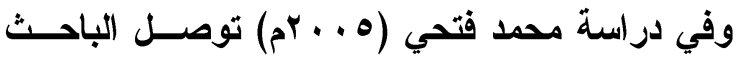
حول وجود علاقــة ايجابيــة بـين دور الأخصـــئي الاجتماعي وبين رواد أسر الأنشة الطلابية في تنمية

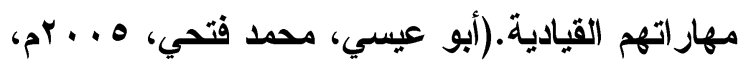

ص: وفي دراسة (الديب، طه عبد العزيز، د. ت، ص: هـ هـ)

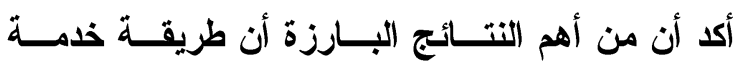

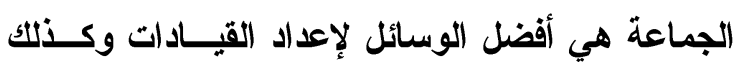

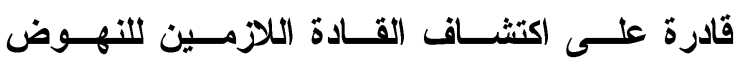

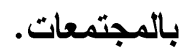




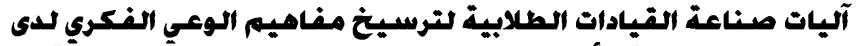

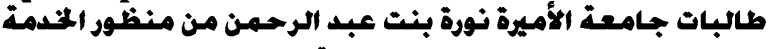
الاجتماعية

د. منال مشـبـ القحطبني - د. نعمة البراهيم عوض

الانفتاح الثقافي وصراع القيم وبروز قيم جديدة فــي ظل ضعف دور المؤسسات التي تقوم بالمساعدة فـــي

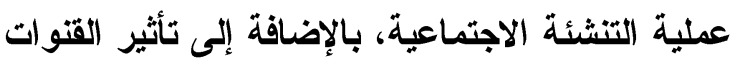

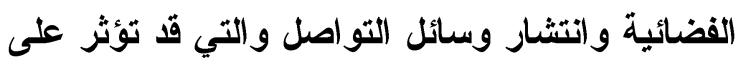
قيم الشباب.

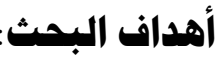

/ أن تتبني كلية الخدمة الاجتماعية تكوين وإعــداد قيادات وسط الطالبات والتي من المتوقع مســاهتهن في ترسيخ الوعي الفكري لاى الطالبات. r / التعرف على الو اقع الفعلي للطالبات القياديات. r/ تسليط الضوء على الأشطة الاجتماعية اللاصفية لاى الطالبات والتي من المتوقع أن تساهم في ترسيخ الوعي الفكري. ع / تسليط الضوء على الأنشطة الثقافية لاى الطالبات والتي من المتوقع أن تساهم فـــي ترسـيخ الــوعي

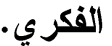

•/ التعرف على الصعوبات والمعوقات التــي تحــول دون تكوين وصناعة القيادات الطلابية.

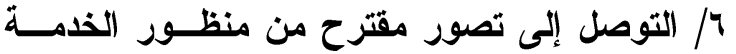

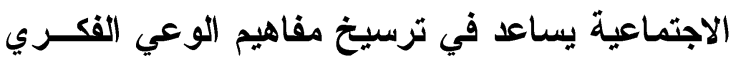

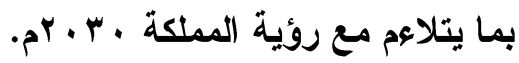

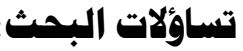

1 - كيف يمكن أن تساهم كلية الخدمة الاجتماعية في تكوين قيادات طلابية قادرة على ترسيخ مفاهيم الوعي

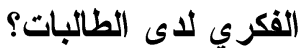

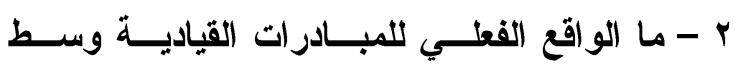

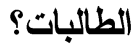
r - ما طبيعة الأنشطة الاجتماعية التي تساعد علــى اكتشاف وصناعة و إعداد القيادات الطلابية؟ ع - ما طبيعة الأنشطة الثقافية التــي تســاعد على اكتشاف وصناعة و إعداد القيادات الطلابية؟ ه - ما الصعوبات والمعوقات التي تحول دون تكوين

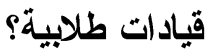

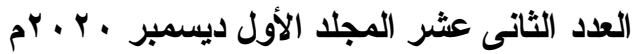

وأكلات دراسة عفاف محمد عبد المنعم (.... r م) أن

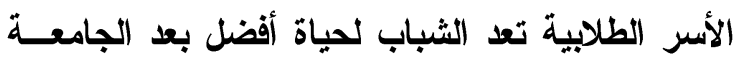
وتغرس داخل نفوسهم الاعتماد على النفس والقــدرة على اتخاذ القرارات المصيرية ذات الصلة بحيــاتهم.

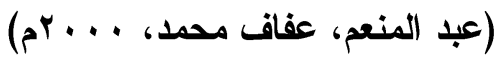

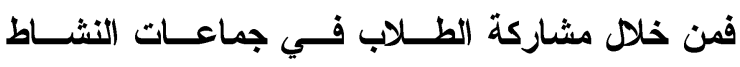

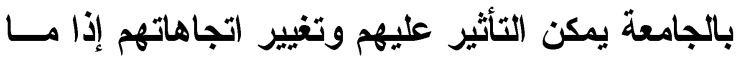

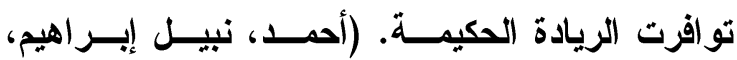
(1) (1): فالإعداد الجيد للشباب الجامعي يهيئ الطالبات لقيــادة المستقبل، ومن هنا يتضح أهمية العمل مي الثباب في

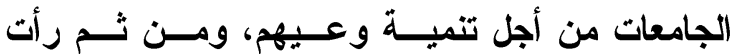
الباحثتان أن هنالك ضرورة لصناعة القيادات الطلابية من خلال ممارسة الأنشطة والتي تتيح التعرف علـى قدرات ومواهب واســتعدادات الطالبــات فــي هـــه

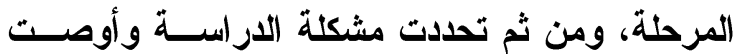
بالخروج بتصور برنامج مقترح لصــناعة القيــادات لترسيخ مفاهيم الوعي الفكري لايهن. كما أثشارت دراسة مجدي محمد مصطفى عبد ربه عن أثثر تذخل الخدمة الاجتماعية لزيادة الوعي التنمـوي بين طلاب الجامعة (عبل ربه، مجدي محمد، ... . بم)

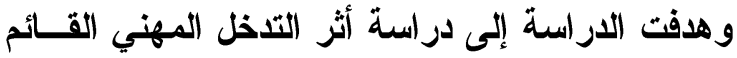

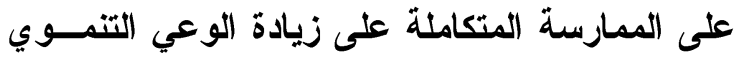
لطلاب الجامعة، وأكلات نتائج الدراسة إلى أن برناميج

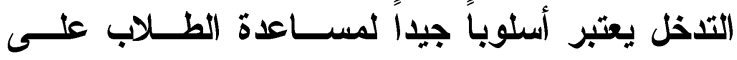

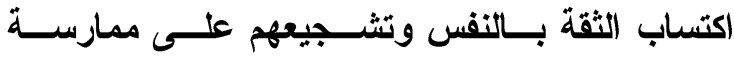
حقوقهم المدنية وإدرالك القــدرة علــى التــأثير فـــي المجتمع.

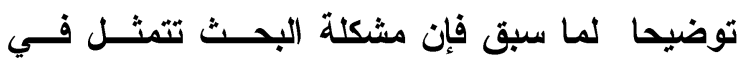

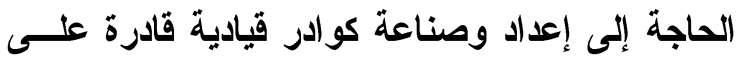

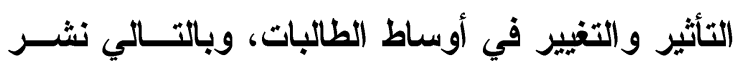

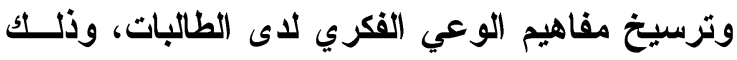

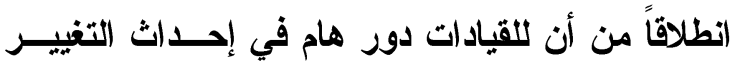

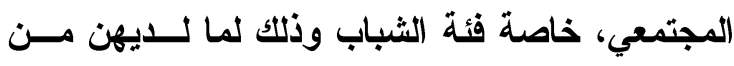
استعدادات وقدرات وطاقات إبداعية، ويأتي ذلك بسبب 


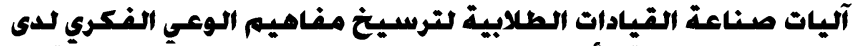

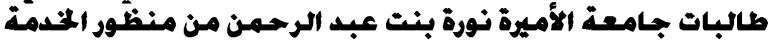
الاجتماعية

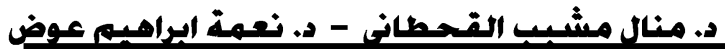

ققد عرفهـ (Awad and Ghaziri, 2004: 33) بأنها الفهم المتحصل من خلال الخبــرة أو الاراســة،

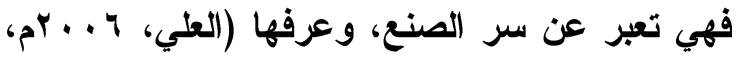

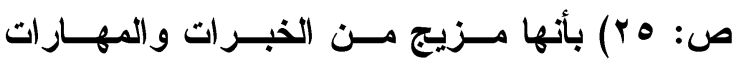

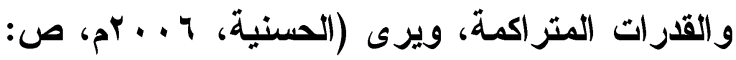

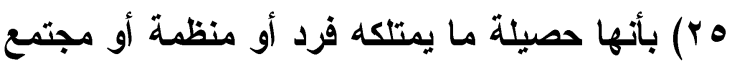
من معلومات وعلم وثقافة في وقت معين.

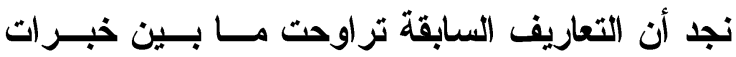

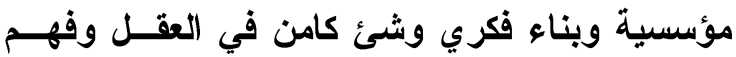
متحصل ومعلومات يمكن استخذامها. ويرتبط مفهوم المعرفة بمفهوم إدارة المعرفــة فهـيـي عمليات تساعد على توليد المعرفة والعصول عليهـا، واختيار ها، وتتظيمها و اســتخلامها ونشــرها، وتعــــ ضرورية في حل المشكلات و التعلم. ويـرى (Awad and Ghaziri, 2004, 3) بـأن إدارة المعرفة هي عملية اكتســاب وعمـل الخبـرة التر اكمية في الأعمال سواء كاتت معرفة صــريحة أو الو ضمنية من خلا الأفكار الموجودة في عقود الأفــراد.

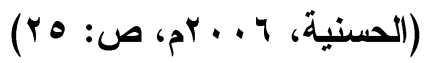
من هنا نجد أن إدارة المعرفة تعني اكتساب المعرفـــة و الاشتر الك بها مع الآخرين والاتتفاع منها وتطبيقها. الاتتفاع بها يعني نقلها من فرد إلى آخر عن طريــق

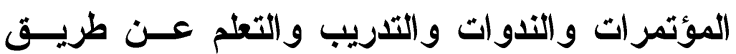
القيادات واستخدامها بفعالية وتطبيقها. ويتم ذلكك من خلال آليات حيث تــــم إدارة المعرفــة وتستخدم في اكتثاف المعرفة، و اكتسابها، والاشتر (ك) بها مع الآخرين وتطبيقها كمثال لذلك المؤتمرات حيث

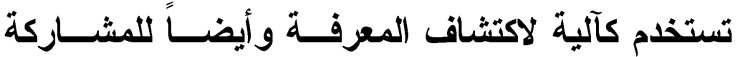

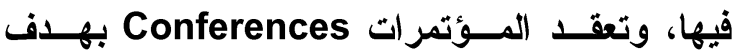
|كتثاف المعارف الموجود لاى الأفراد، كذلك النمذجة/ النماذج Model حيث يستطيع الأفراد مسن خلالهـ

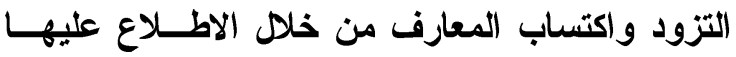
وتطبيق محتواها، المذكرات Memos يتم من خلاهها

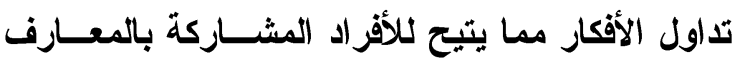

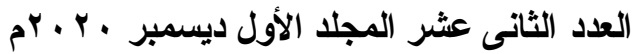

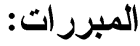

1/ الحاجة إلى صناعة وإعداد واســتثمار القيــادات الثبابية في التغيير الاجتماعي حسب ما أثثارت إليـهـ الكتابات العلميــة وتوصـيات البحسـوث و الاراســات والمؤتمرات حيث أن للقيادة تأثير ومساهمة في إيقاظ الوعي وسط الثباب وتحقيقه على أرض الو اقع مـن خلال ترسيخ الوعي الفكري. r/ قد تساهم الارسة في إثراء ما تميزت به الخدمة

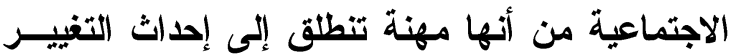

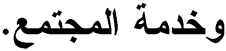

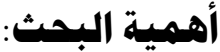

/ انطلاقاً من أهمية دور الجامعات وما تبثــهـ مـنـ ثقافة توعوية في المجتمع الطلابي من خسـلال عـدة وسائل وآليات منها صناعة وتكوين وتطوير القيادات

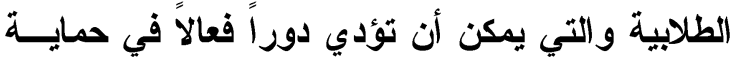
الثقافة الوطنية عند الطلاب من التحـديات الثقافيــة، ومن ثم دورها الراسخ في تحفيز الإبــــاع والابتكـــار والتفكير الثاقب في مواجهة المشــكلات والتحـديات

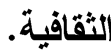
r/ اهتمام الجامعات ومنها كلية الخدمة الاجتماعيـة بجامعة الأميرة نورة بنت عبد الرحمن بالتركيز علـى الاجى

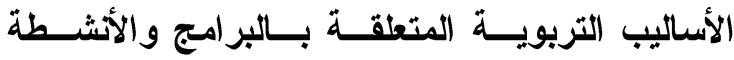
الاجتماعية والثقافية والتي من خلالها يمكن ترسـيخ مفاهيم الوعي الفكري لاى الطالبات. هفاهيه الدراسة: اعتمدت الار اسة على المفاهيم التالية: مفهوم الوعي: يرتبط الوعي بالمعرفة ولنلك لابد من تعريف المعرفة وارتباطها بالوعي. مفهوم المعرفة: هناك آراء حول معنى المعرفة، آراء

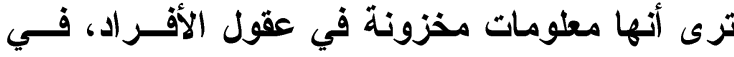

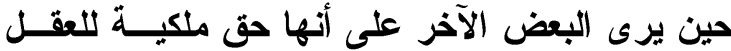

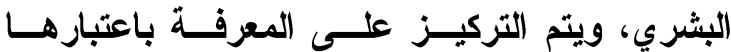
معلومات وخبرة و أبعاد فكرية. 


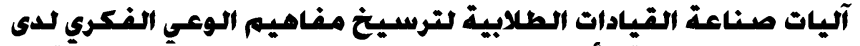

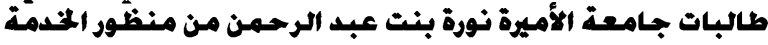
الاجتماعية

د. منال مشيـب القحطبني - د. نعمة ابراهيم عوض

الوعي هو ما يكون لاى الإنسان من أفكار ووجهـات نظر ومفاهيم عن الحياة والطبيعة من حوله.

مفهوم الوعي Awareness:

يعرف الوعي بأنه الإدرالك والإحاطة، ووعاه توعيـة الوعة،

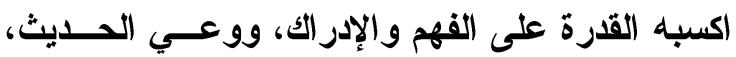

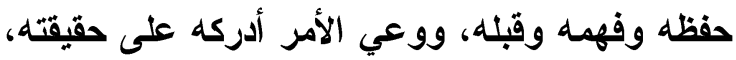

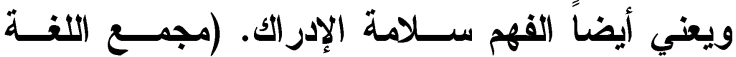

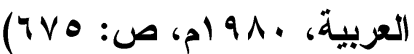
كما يشير مصطلح الوعي لغوياً إلى الفهـــم وســلامة هونة

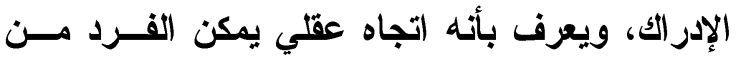

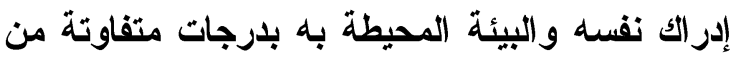

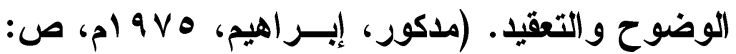

أما معجم ويبستر Webster يشير إلى أن مصـطلح الوعي على معنيـين أساسـيين هــا: ) Neufeld, (1994, p. 296

1 - حالة تيقظ وانتباه الإنسان و إدر اكه لمشاعره ولما

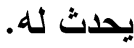
r - مجموع أفكار الفرد ومشاعره و انطباعاته وعقله

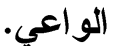
يحدد معجم العلوم الاجتماعية الوعي كلغة ومصــطح

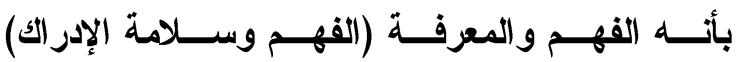
وكمصطلح هو إدرالك الفرد لنفسه وللبيئة المحيطة به وهو على درجات من الوضوح. والوعي بهذا المنــي

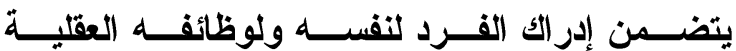
والجسمية و إدراكه لخصائص العالم الخارجي و إدراكه لنفسه باعتباره عوضاً في جماعة، هنا يتعـاظم دوره

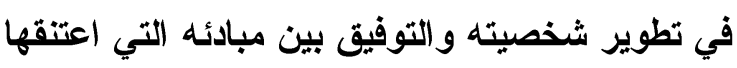

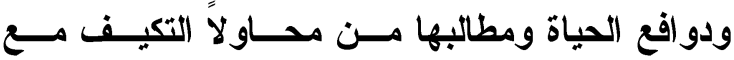

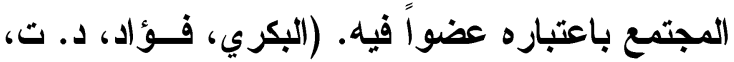

ص: صن ويعرفه آخرون بأنه إدرالك المرع لذاته ولما يحيط به إدراكاً مباشراً أو هو أساس كل معرفة، ويمكن إرجاع

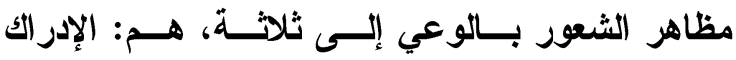

المجلة العلمية للخدمة الاجتماعية

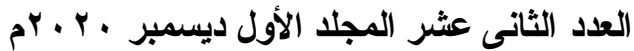

المبادرات Initiation ويتم مسن خلالهــا اكتثــاف المعرفة لاى الأفر اد مسن خــلال تبنــي المبــادرات وتعزيزها لايهم، العروض Presentation ويتم من خلالها مناقشة المعارف الموجودة مما يتـيح زيــادة Learning by المعارف، التعلم من خلا الملاحظة observation معارف جديدة من خلال ملاحظتهم لأفر اد التعلم مسن التن

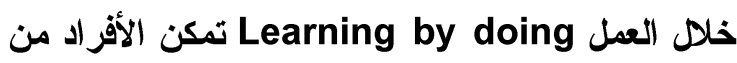
اكتساب المعرفة من خلال الخبرة التي يمارسونها من خلال العمل. الجها التعــاوني/ الممارســات الفضــلى Pest practice موتوقاً ومجدياً يمكن الاعتمـاد، أي المعرفة التي ثبــــ أنها ذات قيمة أو فعالة غفي مواقف محسـدة ويمكــن الاعن تطبيقها، فهي طريقة لاستخدام أفضل الطرق بكةــاءة لتحقيق وانجاز الأهداف المرغوبة. وفيما يتعلق بالمفــاهيم الخاصــة بــالوعي والــوعي الفكري فلابد من الإثشارة إلى مفهوم المعرفة، والتــي لئي

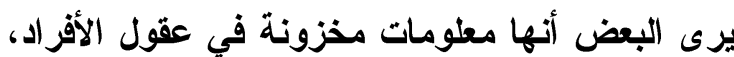
ويرى البعض الآخر بأنها حق ملكية للعقل البثــري. فقد عرفهـ (Awad and Ghaziri, 2004, 33) بأنها الفهم المتحصل من خلال الخبــرة أو الاراســة،

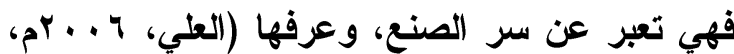

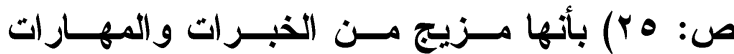
و القدرات المتر اكمة، ويرى (الحسنية، ج ج. بrم، ص:

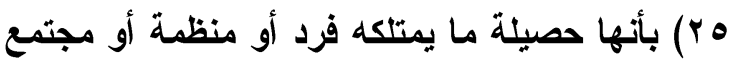
من معلومات وعلم وثقافة في وقت معين.

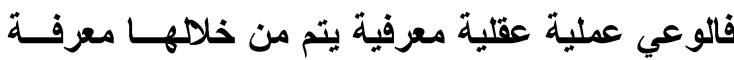

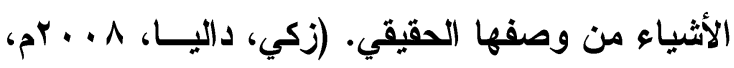

ص: 11) مفهوم الوعي الفكري: الوعي كلمة تعبر عن حالة عقلية يكون فيهــــا العقــل بحالة إدرالك وتواصل مي المحيط الخارجي عن طريق

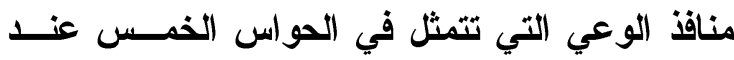
الإنسان(Androw, 2002, p. 48) ، بهذا يكـون 


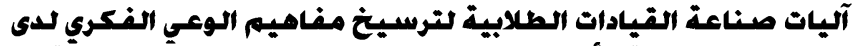

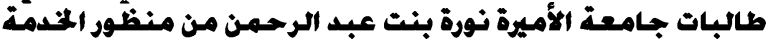
الاجتماعية

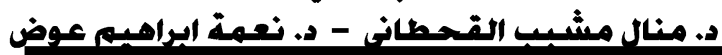

ومن خلال العرض السابق يمكن للباحثتان أن تضــعـع

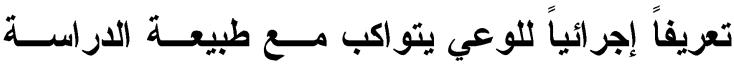

الر اهنة فيما يلي: الئل

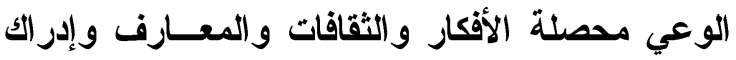
المشكلات الاجتماعية والإحساس بها وتكوين اتجــاه ايجابي لمواجهتها لتغيير الأفكار غير المرغوب فيهـا

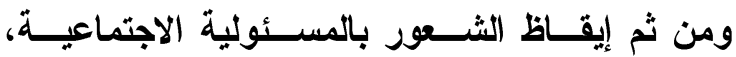

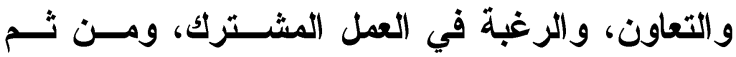

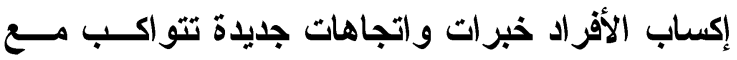
متطلبات ومستجدات الحياة الحديثة فقي تحقيق روئة $\left.\cdot\left(p^{r} \cdot r \cdot\right)^{2}\right)$ أولاً: المفهوم الإجرائي للطالبات القياديات: جماعة من الطالبات يمارسن أنشطة لاصفية متنوعـة بهدف اكتساب وتبادل الخبرات وتنميــة روح الــولاء

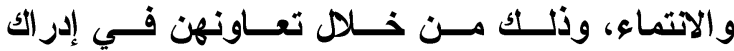
المشكلات الاجتماعية المعاصرة وتغير الأفكــار غيــر المرغوبة من خلال ممارسة النشاطات، وهذه القيادات

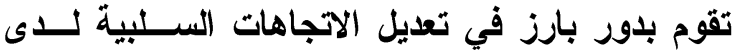
الطالبات و إكسابهن خبرات واتجاهات جديرة تتواكسب لتب

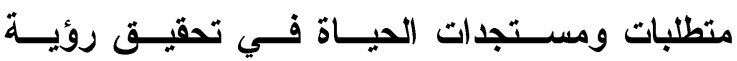
$\cdot\left(a^{r} \cdot r \cdot\right)$

لقد تزايد الاهتمام بتنمية الوعي لاى الشباب وخاصة

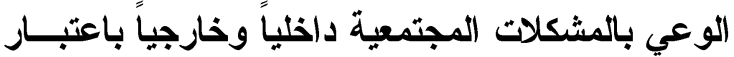
أن الوعي يقوم على مجموعة من الأفكار والتصورات

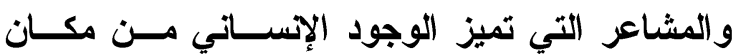

(Franreli, 2001, 45). لآخر والمئ

وباعتبار أن الوعي يتأثر بأنماط العلاقات الاجتماعيــة

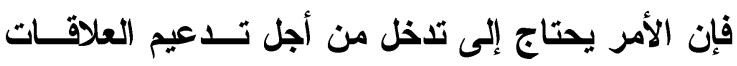

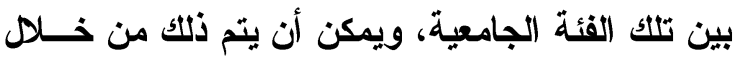
ممارسة الأنشطة مع الجماعات الطلابية، والتي تعتبر الأداة التي من خلاهها يمكن أن تنمي معارف الطالبـــة

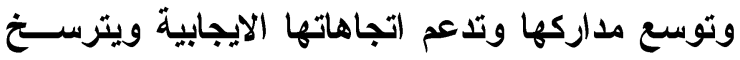
لايها مفاهيم الوعي الفكري.

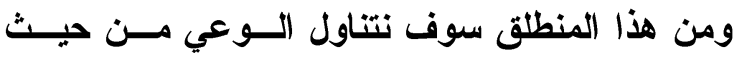
سمات وخصائص الوعي، حيث أنه:
المجلة العلمية للخدمة الاجتماعية

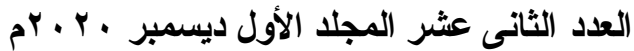

والمعرفة والوجدان أو النــزوع أو الســلوك.(بدوي،

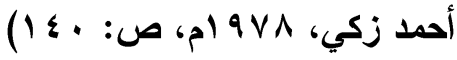
ويشير إليه البعض الآخر بأنه جملة الآراء والمفاهيم

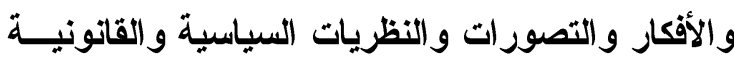
والأخلاقية الممثلة للجاتب الروحي من حياة المجتمع، ونئ

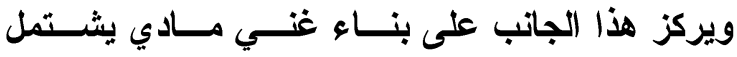
عمليات إنتاج الثروة المادية والعلاقات التي تقوم بين الناس.(فرج، محمد، ه19 ام، ص: ع \& 1)

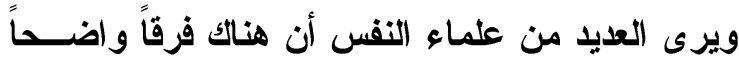

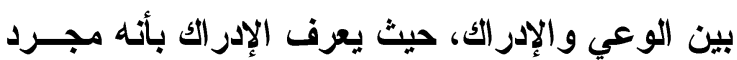

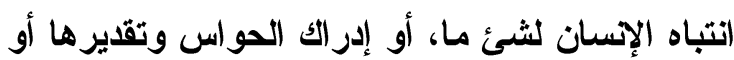

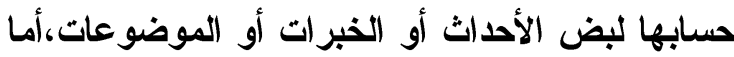

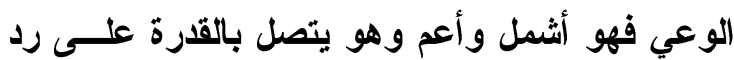

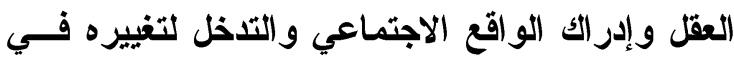
مسرات معينة. (Bwolman,1993,p.35) ويتضمن عدة معاني حيث يشير إلـــى عمليــة كــــن

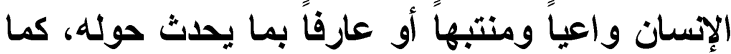

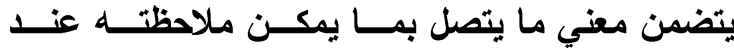
استبطان المر \& لأقكاره ودو افعه ومـا يتصــل بالقـــرة لفرة على العقل كنتيجة لوجود مثير خـــارجي فـــي البيأسـة المحيطة. (lbid, p. 35 - 36) أمـا فيما يتعلق بمفهوم تنمية الوعي، فهو يشير إلــى

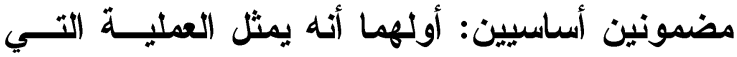
تستهدف مساعدة الفرد على الوصول إلى فهم أوســـع

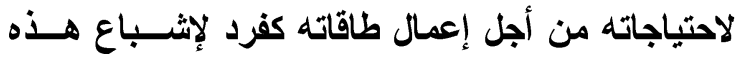
الحاجات، وثانيهما أنه أسلوب يدرك المرء من خلالهه

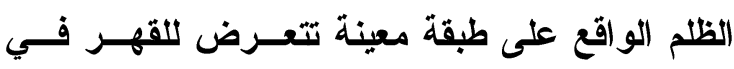

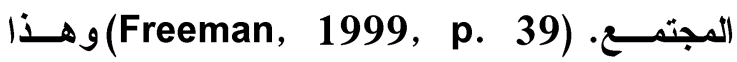
المضمون الثاني لا نعول عليه في هذه الار اسة. كما يشير البعض الآخر إلى تنمية الوعي بأنها عملية

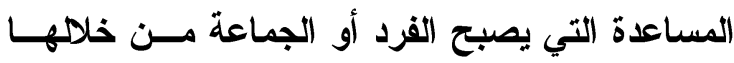

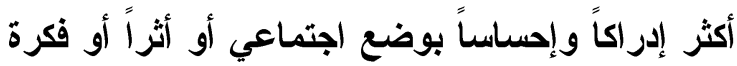

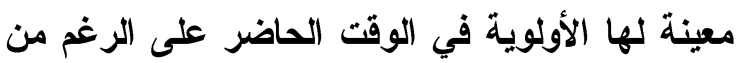
الاهتمام الضعيف تجاهرهـا. ) Balck Jan, 2006 (p. 137 
آلبات صناعة القبادات الطلابية لنرسبخ مفاهبه الوعي الفكري لدى

طالبات جامعة الأميرة نورة بنت عبد الرحمن من منظوّر الخدمة

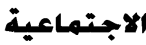

د. منال مشـبـ القحطبانع - د. نعمة البراهيم عوض

وللقيادة خصائص تتميز بها من أهمها أنهــــا تبادليــة

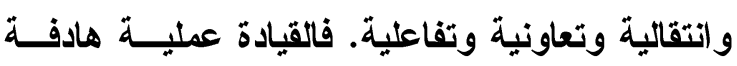

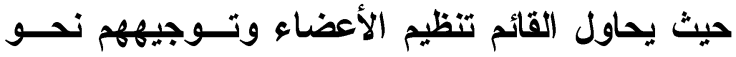

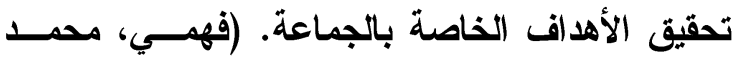

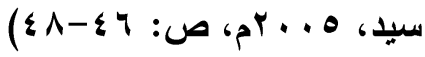

$$
\begin{aligned}
& \text { إعداد القيادات الطلابية: }
\end{aligned}
$$

تتعدد مجالات إعداد القيادات تبعـاً للخــدمات التــي يتضمنها مجال رعاية القيادة، فمنها التعليمي والثقافي

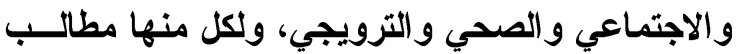

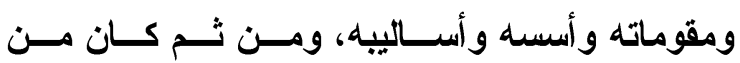
الضروري إعداد القادة لكل مجال منها وضع البرامج لكل إعداد والتدريب عليها. متطلبات إعداد القيادات الطلابية:

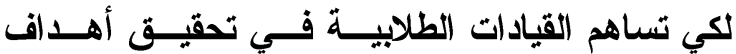

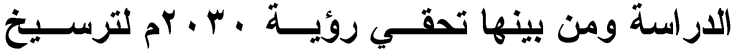
الوعي الفكري يجب أن تتوفر لايهم المتطلبات الآتبة: 1 - وضوح الروية فيما يتصل بالأوضاع الاجتماعية و الثقافية و الاينية.

Y - إبراز أهمية العمل الجماعي الأي تسـوده روح التعاون و التضامن.

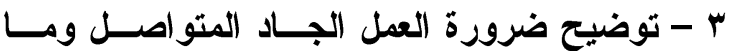
يتطلبه من مهــارات وخبـرات ومعـــارف. (عـــران

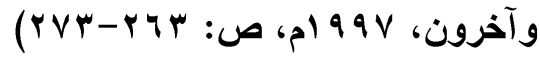

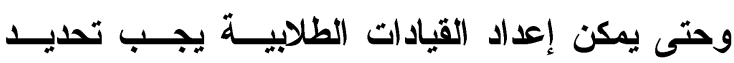
الاحتياجات الأسساسية لتلك القيادة. هنهمية البحث وأدوات جمع البيانات:

يعتبر ابحث من البحوث الوصفية التحليليــة ويحــاول التعرف على آليات صناعة القيادات وسط طالبات كلية

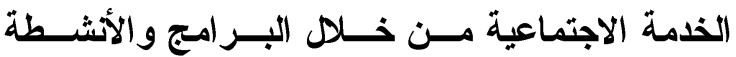
اللاصفية، بالإضافة إلى التعرف على الصعوبات التي تحول دون تحقيق ذلك.

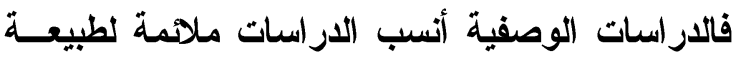
الموضوع، ويتضمن هذا النوع من البحــوث دراســـة الحقائق الراهنة المتعلقة بطبيعة الظاهرة أو الموقــف فلف

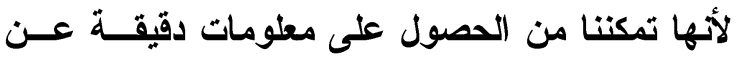

المجلة العلمية للخدمة الاجتماعية

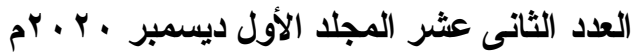

- بتضمن مجموعة من الأفكــار والتصــورات و المشاعر، يختلف الوعي من مجتمع لآخــر

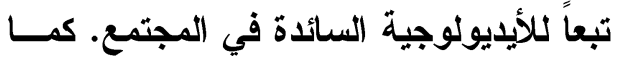
أنه يتأثر بالو اقع المحيط بالإنسان و المجتمع،

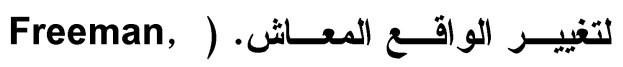
(1999, p. 121

- للوعي مستويات جماعية وفردية ومجتمعية.

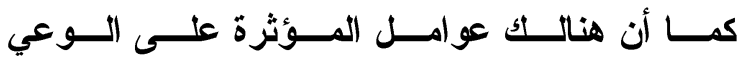
(Androw, 1998, p. 22)

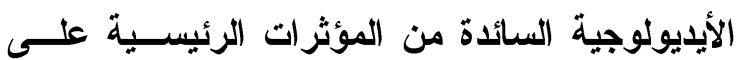
الوعي الإنساني، كذللك وسائل الإعلام فيتأثر الــوعي لهوني بشكل واضح بوسائل الإعــلام باعتبــار أن وســائل الإعلام تقوم بدور هام في تثكيل تصورنا للواقع، كما

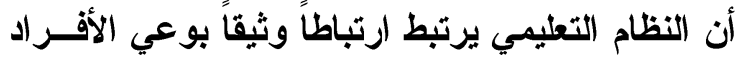

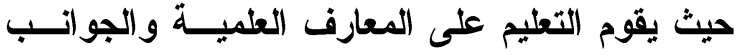

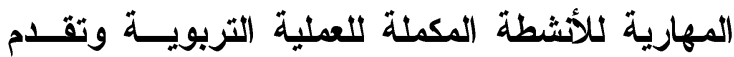
معارف عن التشئة الاجتماعية خلا مراحل التعلـيم حيث يشكل الوعي ويدفع إلى المشاركة الفعالة. مستويات الوعي: - الو الوعي بالعلاقات الاجتماعي، الوعي بالتغير الاجتماعي

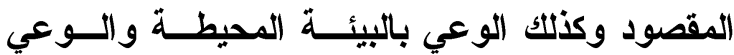

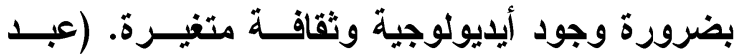

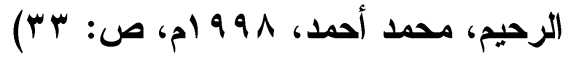
ثانياً: مفهوم القيادات الطلابية: القيادة عملية تربوية اجتماعية لازمة لكل جماعة تريد

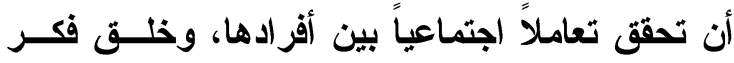
مشترك واتجاهات موحدة بينهم وذلتك لضمان التعاون بين أعضائها في سبيل تحقيق الأهداف المتفق عليها.

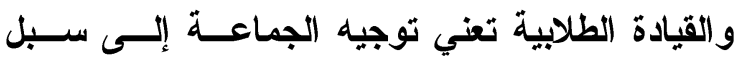

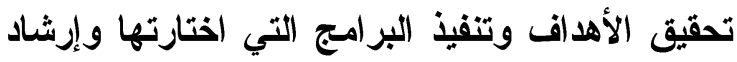

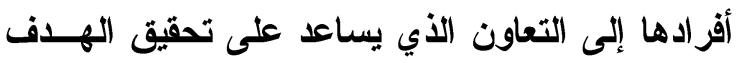

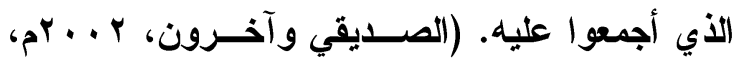

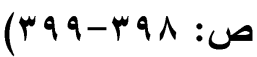
و القيادة الطلابية هي العملية التي تمكن من الإســهام بصورة فعالة في حركة الجماعة نحو أهداف معروفة، 


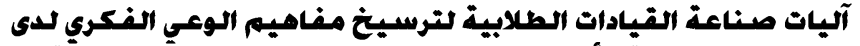

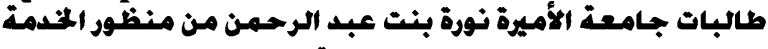
الاجتماعية

د. منال مشـبـ القحطبني - د. نعمة البراهيم عوض

المدروسة وبعد تصــنيف وتعليـلـل البيانــات يمكـن

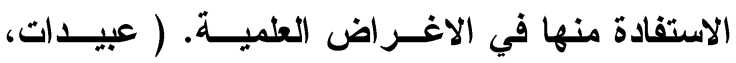

$$
\cdot(r . . \varepsilon
$$

مجتمع وعينة الار اسة:

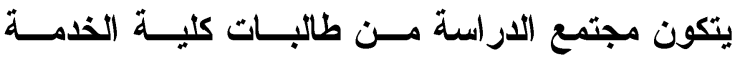

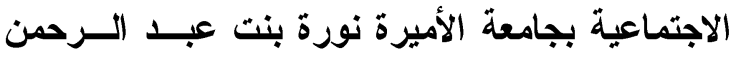

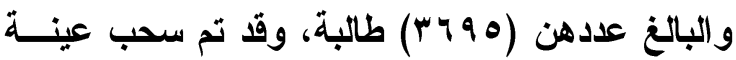

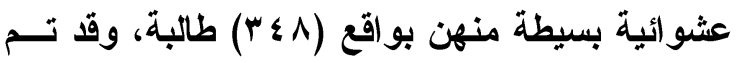
تحديد العينة وفقاً لمعادلة ستيفن ثامبسون.

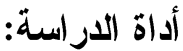
بناء على طبيعة البيانات، وعلى المنهج المتبــع فــي

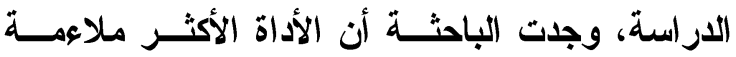

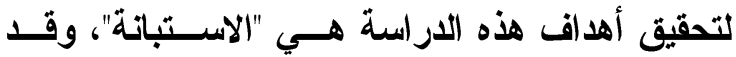
تكونت الاستبانة في صورتها النهائية من (^^م) عبارة موزعة على خمسة محاور تتمثل في (طبيعة الأشطة

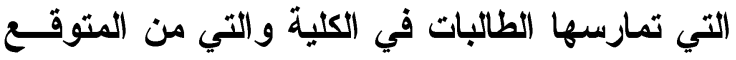

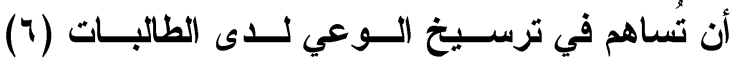
عبارات، مظاهر إسهام الأشطة الطلابية في توعيــة الطالبات (9) عبارات، المعوقات والصــعوبات التــي لوني

تحول دون تكوين وصناعة قيادات طلابية بالكلية (•) عبارات، مهارات القيادة الطلابية التي يجب توفرهــا لتونس لاى الطالبات والتي تُساعد على تنمية وعيهن الفكري (^) عبارات، الوسائل التي تُساعد على تنمية وعــي الطالبات، أهم المقترحات لتفعيل الأنشطة التي تُساعد على تنمية الوعي لاى الطالبات (9) عبارات)، وقد تم الاعتماد على المقياس المتلدج الثلاثي كما في الجدول

$$
\text { رقم (1)، وذلك على النحو التالي: }
$$

كيفية صناعة القيادات الطلابية ودورها فــي ترسـيخ

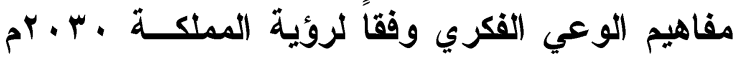

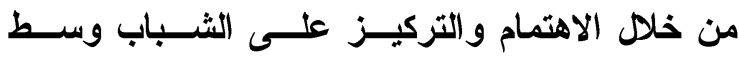

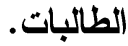
منهجية البحث: سوف تستخلم الباحثتان مـــهج المســــح الاجتمـــاعي

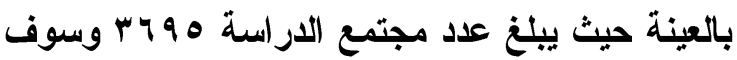
يتم سحب عينة عشوائية منهم عددهم (T ع ب).

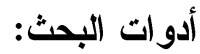
1 - استمارة استبيان تطبق علــى طالبــات جامعــة الاميرة نورة بنت عبدالرحمن كلية الخدمة الاجتماعية.

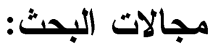

المجال المكاني: كلية الخدمــة الاجتماعيــة بجامعــة الأميرة نورة بنت عبد الرحمن.

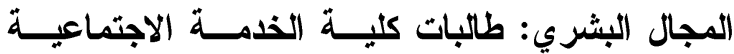
بجامعة الأميرة نورة بنت عبد الرحمن والبالغ عددهم

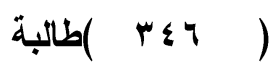

المجال الزمني: وهي فترة إجراء الاراسة الميدانية.

\section{هنهجية الدراسة وإجراءاتها:}

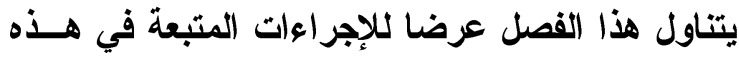
الار اسة، وذلك على النحو التالي: منهج الار اسة:

اتبعت الدراسة منهج المسح الاجتماعي بالعينة، وهو

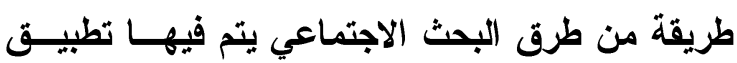

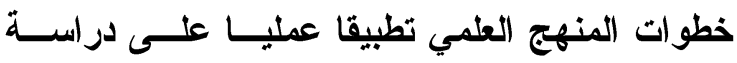
ظاهرة أو مشكلة اجتماعية أو أوضاع اجتماعية معينة سائدة في منطقه جغر افية بحيث نحصل علــى كافـــة

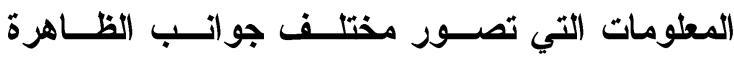

\begin{tabular}{|c|c|c|}
\hline غير موافق / ضعيفة & إلى حـ مـا & موافق / كبيرة \\
\hline r.\&. - r.7l & $\varepsilon . r .-r . \varepsilon)$ & $0 . .-\varepsilon . Y_{1}$ \\
\hline
\end{tabular}
جدول رقم (1) تحديد فئات المقياس المتدرج الثلاثي

الباحثة بإجراعات التعديلات اللازمة حتــى أصــبت الأداة في صورتها النهائية.

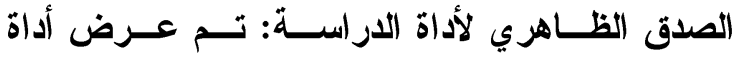

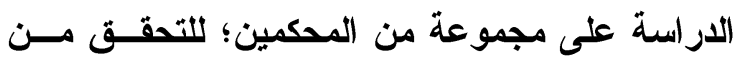

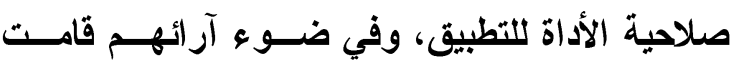




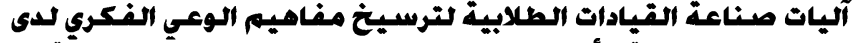

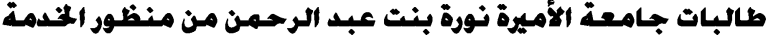
الاجتماعية

د. منال مشـبـ القحطبني - د. نعمة البراهيم عوض

بالتطبيق على عينة اســنطلاعية مـن (ro) طالبــة، وذللك كما يتضح من خلال الجدول رقم (r)، وذلك كما
المجلة العلمية للخدمة الاجتماعية

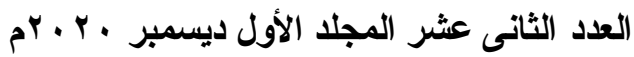

الصدق الظاهري لأداة الدراسة : للتحقى من الصـــق

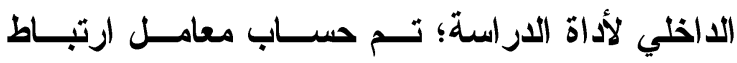
بيرسون بين عبارات المحور والارجة الكلية للمحور، جدول رقم (Y) يوضح معاملات ارتباط بيرسون لعبارات الاستبانة بالدرجة الكلية لكل محور لكور

\begin{tabular}{|c|c|c|c|c|c|c|c|c|c|}
\hline \multicolumn{2}{|c|}{ مقترحات لتفعيل } & \multicolumn{2}{|c|}{ مهار ات القيادة } & \multicolumn{2}{|c|}{ الصعوبات و المعوقات } & \multicolumn{2}{|c|}{ الأشطة في تو إسهام } & \multicolumn{2}{|c|}{ طبيعة الأشطة } \\
\hline معاهل & العبارة & معاهل & العبارة & معامل & العبارة & الارتباط & العبارة & معامل & العبارة \\
\hline$* * . . \Delta r V$ & 1 & $* * . V 19$ & 1 & $* * . . \diamond \wedge r$ & 1 & $* * . . \neg \wedge \mu$ & 1 & $* * .700$ & 1 \\
\hline$* * .77$ & $r$ & $* *, . V Y \varepsilon$ & r & $* *, . V \leqslant 1$ & $r$ & $* * . . \neg \wedge 1$ & $r$ & $* * . . \diamond \wedge \wedge$ & $r$ \\
\hline$* * .9 .9$ & $r$ & $* * . \wedge .9$ & $r$ & $* *, .7, \varepsilon$ & $r$ & $* *, . \wedge .9$ & $r$ & $* * . V Y r$ & $r$ \\
\hline$* * . .7 \vee \varepsilon$ & $\varepsilon$ & $* * . . \vee \wedge r$ & $\varepsilon$ & $* * .799$ & $\varepsilon$ & $* * . \vee \vee q \wedge$ & $\varepsilon$ & $* * . \vee \vee \diamond q$ & $\varepsilon$ \\
\hline$* * . .79 r$ & 0 & $* *, . \Lambda . \varepsilon$ & 0 & $* * . . V Y$. & 0 & $* *, . V \leqslant q$ & 0 & $* *$ *. VY. & 0 \\
\hline$* * . .7 \wedge 9$ & 7 & $* *, . \Lambda \cdot \Lambda$ & 7 & - & - & $* * . . V Y_{1}$ & 7 & $* * . V \mid r$ & 7 \\
\hline$* *, . V r r$ & V & $* *, . \wedge \leq \mu$ & V & - & - & & V & - & - \\
\hline$* * . . \neg \wedge \varepsilon$ & $\Lambda$ & $* * . \wedge r V$ & $\Lambda$ & - & - & & $\Lambda$ & - & - \\
\hline **.. I & 9 & - & - & - & - & & 9 & - & - \\
\hline
\end{tabular}

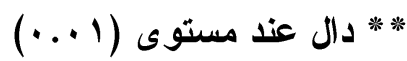

إلى مؤشرات صدق مرتفعة وكافية يمكن الوثوق بهــا

في تطبيق الار اسة الحالية. يتضح من خلال الجدول رقم (r) أن جميع العبــارات ثبات أداة الدراسة : للتحقق من ثبات أداة الدراسة؛ تم لكل محور دالة عند مستوى (1 ...)، وهــذا يعطـي استخدام معامل الفا كرونباخ، وذلتك كما يتضــح مسن دلالة على ارتفاع معاملات الاتساق الاخلي، كما يشير

خلال الجدول رقم (r)، وذلك كما يلي:

جدول رقم (r) معامل ألفا كرونباخ لقياس ثبات أداة الدراسة

\begin{tabular}{|c|c|c|}
\hline 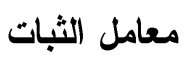 & المحور & م \\
\hline$\cdot . v q r$ & طبيعة الأشطة التي تمارسها الطالبات في الكلية و التي من المتوقع أن تُساهم في & 1 \\
\hline..$\wedge 90$ & مظاهر إسهام الأشطة الطلابية في توعية الطالبات. & r \\
\hline$\cdot v$. & المعوقات والصعوبات التي تحول دون تكوين وصناعة قيادات طلابية بالكلية. & r \\
\hline $.91 \varepsilon$ & مهارات القيادة الطلابية التي يجب توفرها لدى الطالبات والتي تُساعد على تنمية & $\varepsilon$ \\
\hline . Aro & أهم المقترحات لتفعيل الأشطة التي تُساعد على تنمية الوعي لاى الطالبات. & ○ \\
\hline
\end{tabular}




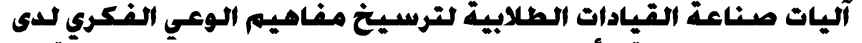

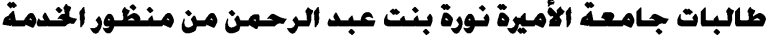
الاجتماعية
المجلة العلمية للخدمة الاجتماعية

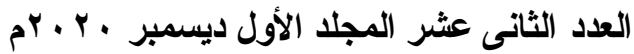

د. منال مشيـب القحطاني - د. نعمة ابراهيم عوض

$.9+$

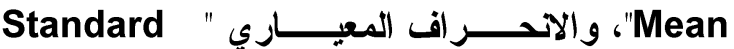
Deviation " وذلك لمعرفة مدى ارتفاع أو انخفاض استجابات أفراد عينة الاراسة عن المحاور الرئيســة (متوسطات العبار ات). عرض نتائج الار اسة ومناقشتها يتتاول هذا الفصل عرض نتائج الدارســـة الميداتيــة

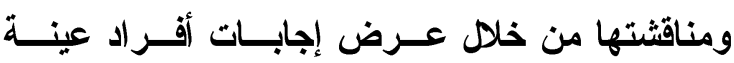
الار اسة على عبارات الاستبانة وذللك من خلا عل الإجابة على تساؤلات الاراسة على النحو التالي:

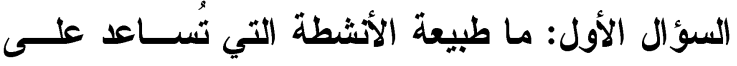
اكتشاف وصناعة و إعداد القيادات الطلابية؟

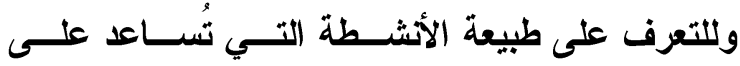
اكتشاف وصناعة و إعداد القيادات الطلابية، تم حساب الاسئ والاحرر اف المعياري لاستجابات أفراد الاراسة، كما تم ترتيب هذه العبارات حسب المتوسط الحســابي لكــلاً

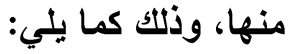

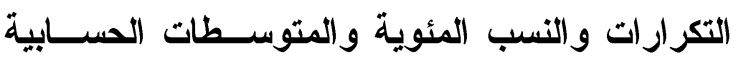

الثبات الكلي للأداة

يتضح من خلال الجدول رقم (r) أن استبانة الاراسة تتمتع بثبات مقبول إحصائياً، حيث بلغت قيمة معامـلـل الثبات الكلية (ألفا) ( . .9. •)، كما تراوحت معاملات

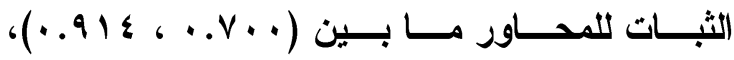
وجميعها معاملات ثبات عالية يمكن الوثوق بها فــي تطبيق أداة الدراسة الحالية. مجالات الار اسة: تمثلت مجالات الاراسة الحالية فـــي المجال المكاني و البثري والزمني، وذللك على النحسـو

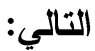
المجال المكاني: كلية الخذمــة الاجتماعيــة بجامعـة الأميرة نورة بنت عبد الرحمن.

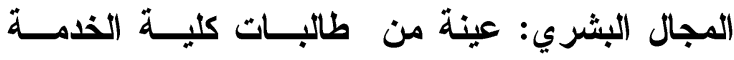

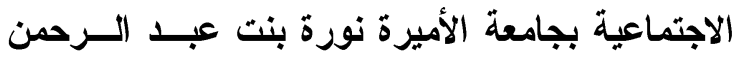
و البالغ عددهن(

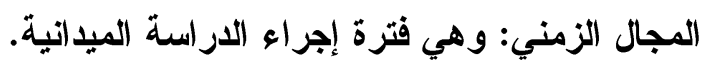

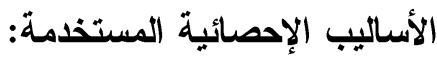

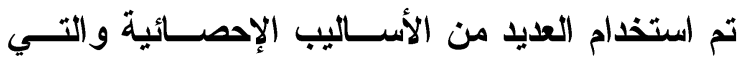
تتمثل في: التكرارات والنسب المئوية، معامل ارتبـاط الإسط بيرسون(Pearson correlation) لحساب صــلق الاتساق الدّاخلي لأداة الدراسة، معامـل ألفاكرونبــاخ لحســاب معامـل ثبــات (Cronbach's Alpha) المحاور المختلفة لأداة الاراسة، المتوسط الحسابي "

جدول رقم (ع) يوضح طبيعة الأنشطة التي تساعد على اكتثاف وصناعة وإعداد القيادات الطلابية

\begin{tabular}{|c|c|c|c|c|c|c|c|c|c|c|}
\hline \multirow{3}{*}{ E: } & \multirow{3}{*}{$\begin{array}{ll}5 & \underline{6} \\
\frac{E}{5} & \underline{E} \\
\underline{E} & \underline{2}\end{array}$} & \multirow{3}{*}{$\underline{E}$} & \multicolumn{6}{|c|}{ درجة الممارسة } & \multirow{3}{*}{ العبار ات } & \multirow{3}{*}{ b } \\
\hline & & & \multicolumn{2}{|c|}{ ضعيفة } & \multicolumn{2}{|c|}{ متوسطة } & \multicolumn{2}{|c|}{ كبيرة } & & \\
\hline & & & $\%$ & ك5 & $\%$ & ك5 & $\%$ & ك5 & & \\
\hline 1 & $.0 \varepsilon$ & Y.१. & Y.r & $\wedge$ & ro.r & Irr & Tr.\& & YIV & الأشطة الاجتماعية. & $r$ \\
\hline r & $.7 \varepsilon$ & T.Tr & 9.0 & rr & $\varepsilon 9 . \varepsilon$ & IVY & $\{1.1$ & $1 \leqslant r$ & الأثشطة الثقاقية. & 1 \\
\hline$r$ &. .79 & T.YO & $1 \varepsilon .1$ & $\varepsilon 9$ & $\leq 7.7$ & $19 r$ & rq. & $1 T V$ & الأنشطة الفكرية. & $\varepsilon$ \\
\hline$\varepsilon$ & $\cdot v 1$ & r.17 & $1 \wedge . \varepsilon$ & $7 \varepsilon$ & $\varepsilon V .1$ & $17 \varepsilon$ & $r \leqslant .0$ & ir. & الأشططة القنية. & 0 \\
\hline 0 & $\cdot v$. & T.1 & $1 \wedge . V$ & 70 & $\varepsilon \wedge .7$ & 179 & rr.A & $11 \varepsilon$ & الأنثطة الصحية. & $r$ \\
\hline 7 & .64 & 1.11 & rq.v & Ir & rq.z & ITV & ri.. & Vr & الأنشطة الريفية. & 7 \\
\hline- & $\because \varepsilon V$ & Y.YI & & & & & الحساب & المتوب & & \\
\hline
\end{tabular}




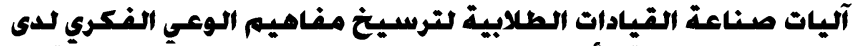

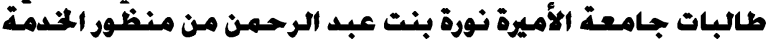
الاجتماعية

د. منال مشـبـ القحطبني - د. نعمة البراهيم عوض

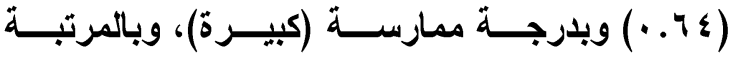

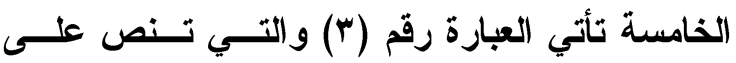

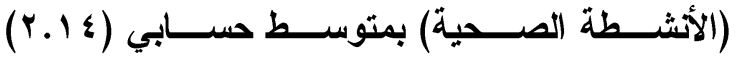

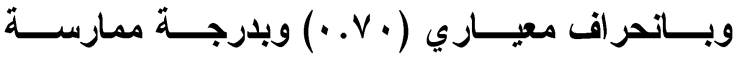
(متوسطة)، وفي الأخير تأتي العبارة رقم (†آ) و والتـــي

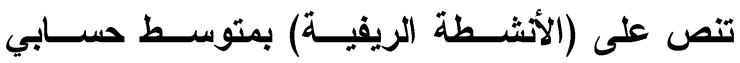

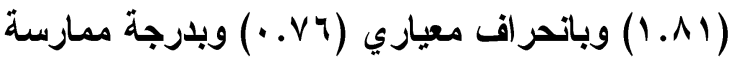

(متوسطة).

السؤال الثاني: ما مظاهر إسهام الأشطة الطلابية في

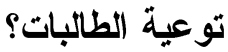
وللتعرف على مظاهر إسبهام الأشطة الطلابيــة فــي توعية الطالبات، تم حساب التكرارات والنسب المئوية و المتوســـطات الحســـابية والآحــــر اف المعيــاري لاستجابات أفراد الارسةة، كما تم ترتيب هذه العبارات حسب المتوسط الحسابي لكلا منها، وذلك كما يلي:
المجلة العلمية للخدمة الاجتماعية

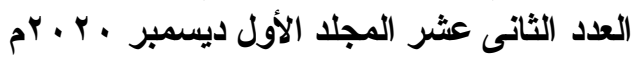

يتضح من الجدول رقم (ع) أن محور طبيعة الأنشطة التي تُساعد على اكتشاف وصناعة و إعداد القيــادات

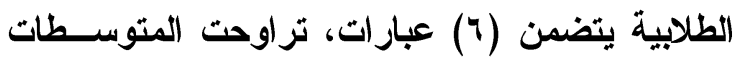

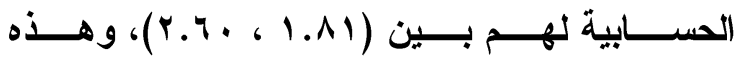
المتوسطات تقع بالفئتين الثاتية والثالثة مـن فئسـات المقياس المتدرج الثلاثي، وتثشير التتيجة السابقة إلى

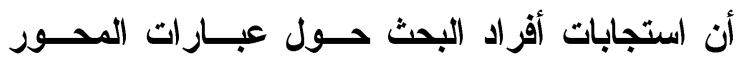
تتر اوح ما بين درجة ممارسة (متوسطة إلى كبيرة).

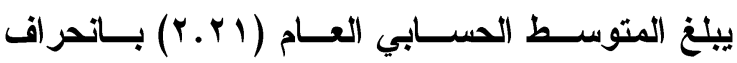

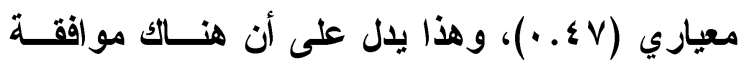
بلرجة متوسطة بين الطالبات على الأنشطة التي يــتم

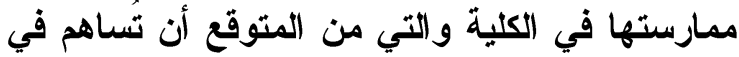
ترسيخ الوعي لاى الطالبات، حيث جاءت العبارة رقم (r) والتي تنص على (الأشطة الاجتماعية) بالمرتبة لونية

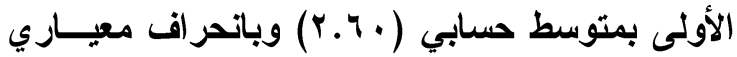

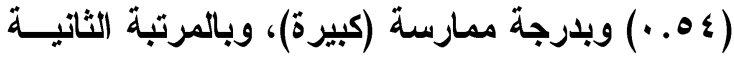

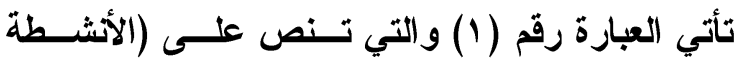

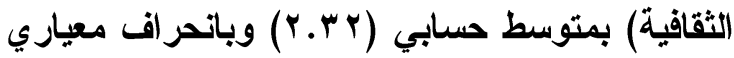
جدول رقم (ه) يوضح مظاهر إسهام الأنشطة الطلابية في توعية الطالبات

\begin{tabular}{|c|c|c|c|c|c|c|c|c|c|c|}
\hline \multirow{3}{*}{ E: } & \multirow{3}{*}{ 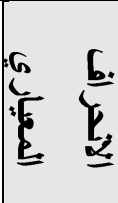 } & \multirow{3}{*}{$\underline{E}$} & \multicolumn{6}{|c|}{ درجة الموافقة } & \multirow{3}{*}{ 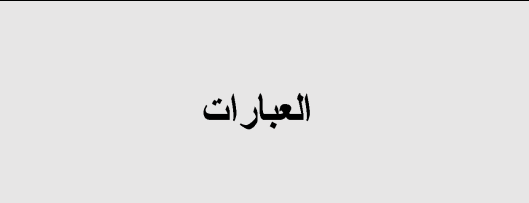 } & \multirow{3}{*}{ r } \\
\hline & & & \multicolumn{2}{|c|}{ ضعيفة } & \multicolumn{2}{|c|}{ متوسطة } & \multicolumn{2}{|c|}{ كبيرة } & & \\
\hline & & & $\%$ & كو & $\%$ & ك & $\%$ & st & & \\
\hline 1 &..$\leqslant r$ & r.^. & $1 . \varepsilon$ & $\bullet$ & IV.. & 09 & 11.7 & 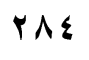 & تساهم في بث روح العمل الجماعي. & 9 \\
\hline$r$ & $\cdot . \leqslant \varepsilon$ & r.^. & $1 . \varepsilon$ & $\bullet$ & IV.r & 7. & N1.r & rAr & تألعاعدال الطالبات على المشاركة في & $\wedge$ \\
\hline$r$ &..$\varepsilon V$ & r.V^ & r.r & $\wedge$ & IV.0 & 71 & $\Lambda . . r$ & $r v q$ & اكساب مهارة المناقشة الجماعية. & $\mu$ \\
\hline$\varepsilon$ & $\cdot . \varepsilon 9$ & r.Vo & r. & 9 & $r \cdot .1$ & v. & VV.r & rqq & اكتساب مهارة الحوار . & $\varepsilon$ \\
\hline$\bullet$ &..$\leqslant 4$ & r.Vr &. .7 & $r$ & ro.q & 9. & VT.T & roq & تدعيم مبادئ وقيم المواطنة والاتتماء. & r \\
\hline 7 &..$\varepsilon V$ & r.V &. .9 & $r$ & ro.9 & 9. & Vr.r & ros & ترسيخ قيم المسئولية الاجتماعية. & 1 \\
\hline$v$ & $.0 \mathrm{r}$ & r.V. & $r . r$ & 11 & $r \leq .1$ & $\wedge \varepsilon$ & Vr.V & ror & تشجيع الطالبات على عمل مبادرات & v \\
\hline$\wedge$ &. .01 & r.TV & r.• & v & 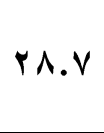 & $1 \cdots$ & 79.4 & $r \leqslant 1$ & إتاحة الفرصة للطالبات للمشاركة & $\bullet$ \\
\hline 9 &. $.7 \varepsilon$ & Y.०६ & V.A & $r v$ & $r \cdot . v$ & $1 \cdot v$ & 71.0 & YI纟 & إتاحة الفرصة للطالبات للمشاركة & 7 \\
\hline
\end{tabular}




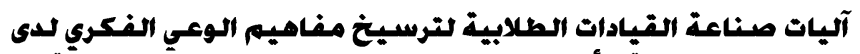

طالبات جامعة الأميرة نورة بنت عبد الرحمن من منظور الخدمة

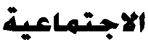

د. منال مشيـب القحطانى - د. نعمة البراهيم عوض

\begin{tabular}{|c|c|c|c|c|c|c|c|c|c|c|}
\hline \multirow{3}{*}{$E_{i}^{E_{:}}$} & \multirow{3}{*}{ 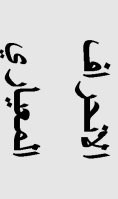 } & \multirow{3}{*}{$E$} & \multicolumn{6}{|c|}{ درجة المو (ققة } & \multirow{3}{*}{ العبار ات } & \\
\hline & & & \multicolumn{2}{|c|}{ ضعيفة } & \multicolumn{2}{|c|}{ متوسطة } & \multicolumn{2}{|c|}{ كبيرة } & & p \\
\hline & & & $\%$ & ك5 & $\%$ & ك5 & $\%$ & ك & & \\
\hline & & & & & & & & & بالمسابقات الاولية . & \\
\hline- &.$r V$ & r.Vr & & & & & & - & & \\
\hline
\end{tabular}

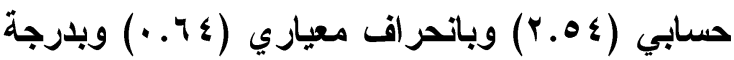

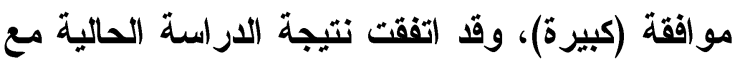

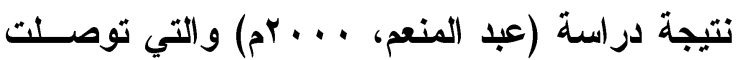

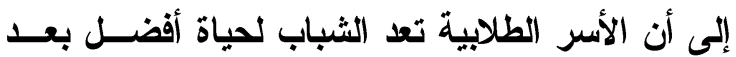
الجامعة وتغرس داخل نفوسهم الاعتماد على الــنفس

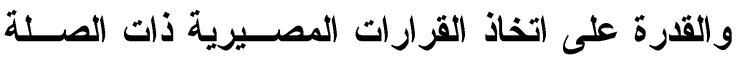
بحياتهم، كما اتفقت نتيجة الاراسة الحالية مع نتيجــة

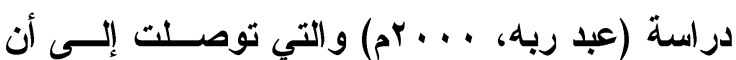

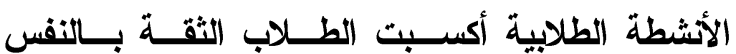

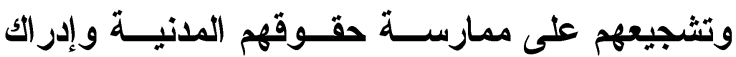
القدرة على التأثير في المجتمع، وقد اختلفــت نتيجـة الار اسة الحالية مع نتيجة دراسة الزهر اني (9 ( • rم) والتي توصلت إلى أن دور الأنثطة الطلابية في تنمية بعض القيم لاى طلبة جامعة أم القــرى فـــ ضــوه الاتجاهات العالمية المعاصرة كان متوسطاً.

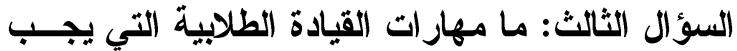
توفرها لاى الطالبات والتي تساعد على تنمية وعيهن

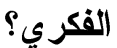
وللتعرف على مهار ات القيادة الطلابيــة التــي يجـب توفرها لاى الطالبات والتي تُساعد على تنمية وعيهن الفكري، تم حســاب التكــرارات والنســب المئويــة

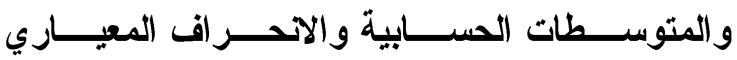

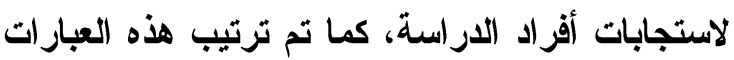
حسب المتوسط الحسابي لكلاً منها، وذلك كما يلي:
يتضح من الجدول رقم (0) أن محور مظاهر إســـهام

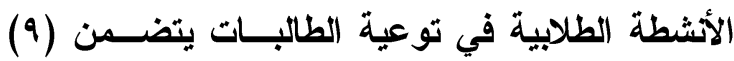
عبارات، تراوحت المتوسطات الحســابية لهـــ بــين

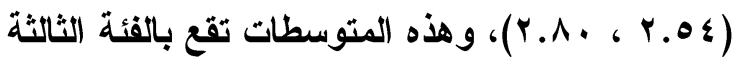
من فئات المقياس المتدرج الثلاثي، وتثــير النتيجــة السابقة إلى أن استجابات أفراد البحث حول عبـارات المحور جاءت بدرجة استجابة (كبيرة).

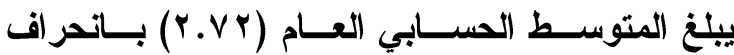

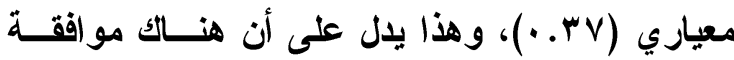

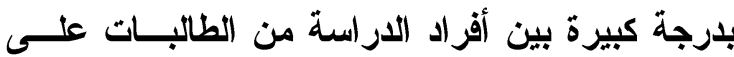
مظاهر إسهام الأنثطة الطلابية في توعية الطالبــات، لاتهات حيث جاعت العبارة رقم (9) و التي تنص على (تساهم في بث روح العمل الجماعي) بالمرتبة الأولى بمتوسط

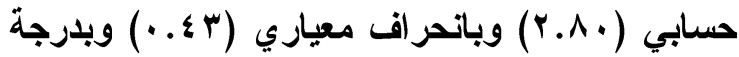

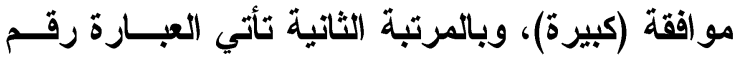
(^) والتي تنص على (تساعد الطالبات على المشاركة

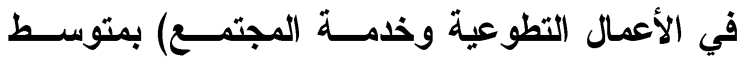

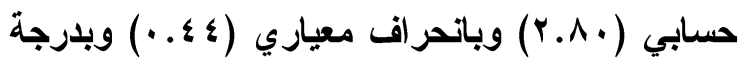
مواققة (كبيرة)، وبالمرتبة قبل الأخيرة (الثامنة) تأتي

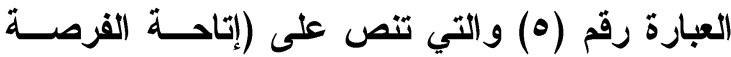

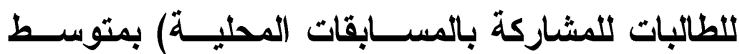

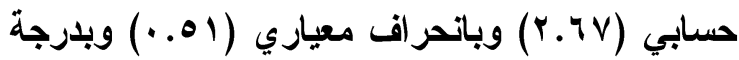
موافقة (كبيرة)، وبالمرتبة التاسعة والأخيـرة تسأتي

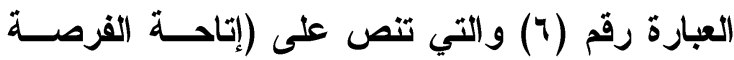

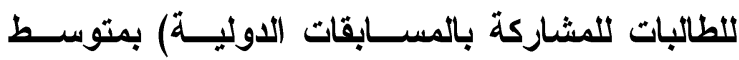


آلبات صناعة القبادات الطلابية لترسبخ مفاهبه الوعي الفكري لدى

طالبات جامعة الأميرة نورة بنت عبد الرحمن من منظور الخدمة الخدية

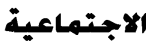

المجلة العلمية للخدمة الاجتماعية

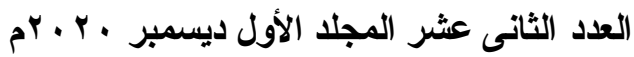

د. منال مشيسب التحطبني - د. نعمة ابراهيم عوض

جدول رقم (؟) يوضح مهارات القيادة الطلابية التي يجب توفرها لاى الطالبات والتي تُساعد على تنمية وعيهن

الفكري

\begin{tabular}{|c|c|c|c|c|c|c|c|c|c|c|}
\hline \multirow{3}{*}{ E: } & \multirow{3}{*}{$\stackrel{5}{E}$} & \multirow{3}{*}{$E$} & \multicolumn{6}{|c|}{ درجة المواققة } & \multirow{3}{*}{ 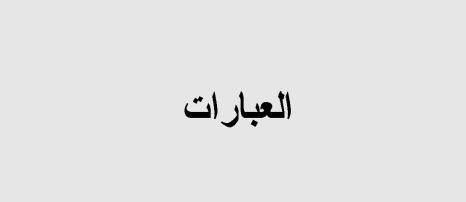 } & \multirow{3}{*}{ r } \\
\hline & & & \multicolumn{2}{|c|}{ ضعيفة } & \multicolumn{2}{|c|}{ متوسطة } & \multicolumn{2}{|c|}{ كبيرة } & & \\
\hline & & & $\%$ & ك & $\%$ & ك & $\%$ & ك & & \\
\hline 1 & $\cdot . \leqslant 0$ & r.Vo & r.9 & 1. & $r \cdot .0$ & $1 \cdot 7$ & $94 . V$ & rmt & القدرة على المشاركة في إعداد & 1 \\
\hline$r$ &. .84 & r.Vo & ro.. & $\Lambda \vee$ & $\leqslant 1.1$ & $1 \leqslant r$ & $r r . q$ & 111 & القدرة على تنفيذ وانجاز الأشطة & r \\
\hline$r$ &. .89 & Y.V $\varepsilon$ & $1 \cdot .9$ & $r \wedge$ & $\varepsilon \cdot r$ & $1 \varepsilon$. & $\varepsilon \wedge .9$ & IV. & القدرة على التجديد والابتكار في & $\varepsilon$ \\
\hline$\varepsilon$ & $\cdot . \leqslant V$ & Y.V & 11.0 & $\varepsilon$. & $\varepsilon r . \Lambda$ & $1 \leqslant 9$ & $\varepsilon 0 . V$ & 109 & القدرة على اتخاذ القرار في تنفيذ & 0 \\
\hline$\bullet$ & $\cdot . \leqslant \wedge$ & r.VY & 1.1 & $\varepsilon$ & YY.\& & $\vee \wedge$ & V५. & YчY & القدرة على المتابعة و التقويم & $\checkmark$ \\
\hline 7 & .0 & r.V. & $r . r$ & 11 & ro. & $\wedge 9$ & VI.r & $r \leqslant \wedge$ & القدرة على التقويم للأششطة & $\wedge$ \\
\hline V & . Or & Ү.१^ & 0.0 & 19 & or.. & 111 & $\{r .0$ & $1 \leqslant 1$ & القدرة على الاتصال الفعال & $r$ \\
\hline$\Lambda$ & ror & Y.TV & $\cdot .9$ & $r$ & $r r .$. & $\Lambda$. & V..1 & YTo & القدرة على تقدير المواقف & 7 \\
\hline- & .09 & T.VT & & & & & ي العام & الحد & المتو & \\
\hline
\end{tabular}

(1) والتي تنص على (القدرة علــى المشـــاركة فـــي

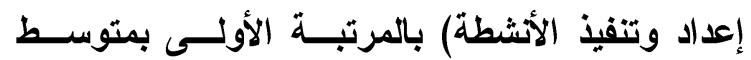

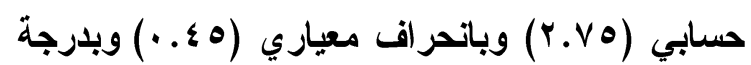

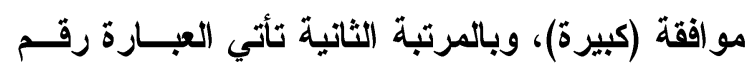

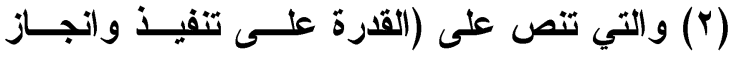
الأشطة) بمتوسط حسابي (Y.V0) وباتحر اف معياري

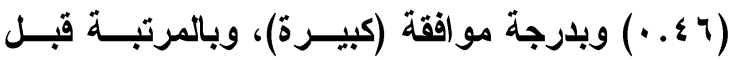

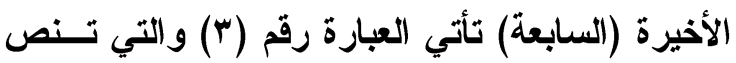
على (القدرة على الاتصال الفعال بالطالبــات والإدارة)

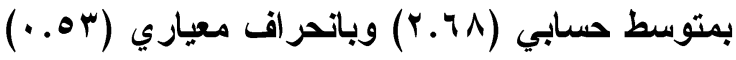
وبلرجة موافقة (كبيرة)، وبالمرتبة الثامنة والأخيـرة تأتي العبارة رقم (†) والتي تنص على (القدرة علــى تقدير المو اقف الخاصة بمشكلات الطالبات) بمتوسـط النط
يتضح من الجدول رقم (؟) أن محور مهارات القيادة الطلابية التي يجب توفرها لاى الطالبات والتي تُساعد على تنمية وعيهن الفكـري يتضـــن (^) عبـار ات، تراوحت المتوسطات الحسابية لهـم بـين (V.TV) ه.V. و وهذه المتوسطات تقع بالفئة الثالثة من فئات المقياس المتدرج الثلاثي، وتثير النتيجة السابقة إلى أن استجابات أفراد البحث حول عبارات المحور جاعت النابه بلرجة استجابة (كبيرة). يبلغ المتوســط الحســابي العــام (Y.VY) بــاتحر اف

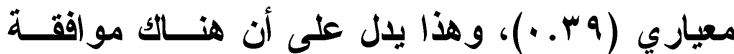

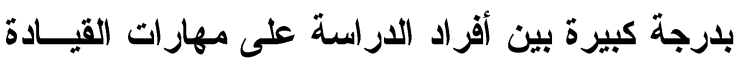
الطلابية التي يجب توفرها لاى الطالبات والتي تُساعد على تنمية وعيهن الفكري، حيث جاعت العبارة رقـم 


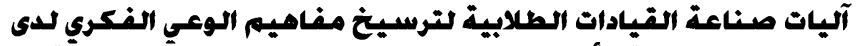

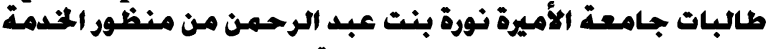
| الاجتماعية

د. منال مشـبـ القحطبني - د. نعمة البراهيم عوض

المسؤولية من أبرز القيم التي يتم تنميتها لاى طلبــة جامعة أم القرى.

السؤال الر ابع: مـا الوسائل التي تُساعد علــــ تنميــة

وعي الطالبات؟

وللتعرف على الوسائل التي تُساعد على تنمية وعــي

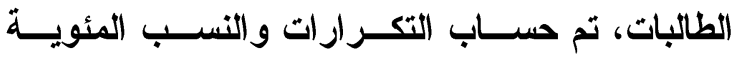

لاستجابات أفر اد الار اسة، وذلك كما يلي:
المجلة العلمية للخدمة الاجتماعية

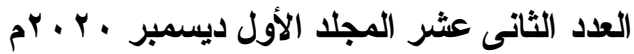

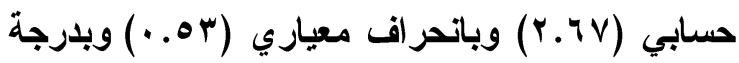

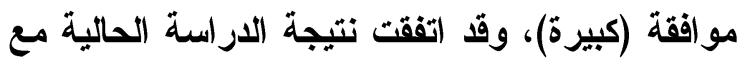

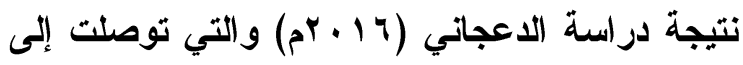
أن مهارات الاتصال والمبادأة والابتكار واتخاذ القرار

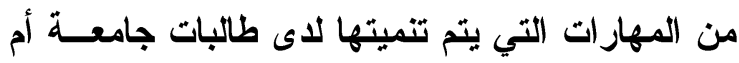

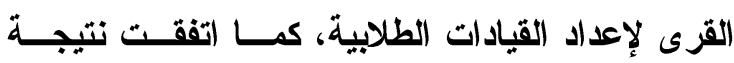

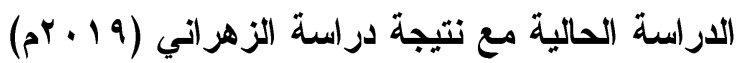

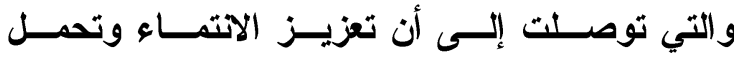
جدول رقم (؟) يوضح الوسائل التي تُساعد على تنمية وعي الطالبات

\begin{tabular}{|c|c|c|c|}
\hline النسبة المئوية & التكر ارات & الوسائل & p \\
\hline $90 . V$ & Trr & الحوار & $r$ \\
\hline $9 \leq .1$ & rr. & المناقشة الجماعية & 1 \\
\hline$\diamond \wedge . \cdot$ & $r \cdot r$ & المعكر ات & $r$ \\
\hline$\wedge r .9$ & rar & الرحلات & $\varepsilon$ \\
\hline$v 9.9$ & rVA & الندوات & ○ \\
\hline 91.1 & MIV & الاجتمـاعات & 7 \\
\hline
\end{tabular}

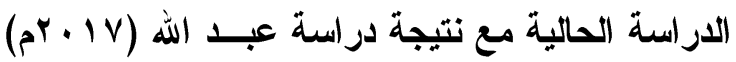
يوضح الجدول رقم (†) الوسائل التي تُســاعد عـــى والتي توصلت إلى أن التدوات وورش العمل من أبرز

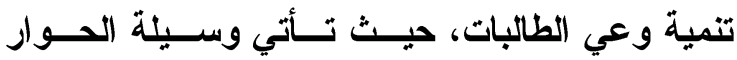
الوسائل التي تستخدمها الجامعات المصرية في تحقيق

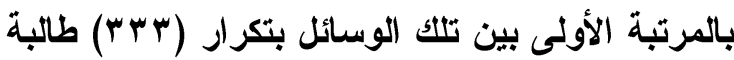
الأمن الفكري لاى طلابها.

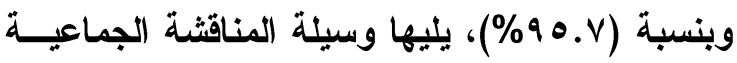

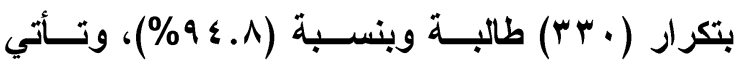
السؤال الخامس: ما الصعوبات التي تحول دون تكوين وصناعة قيادات طلابية بالكلية؟ وسيلة الاجتماعات بالمرتبة الثالثة بين الوسائل التــي

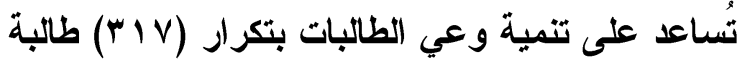

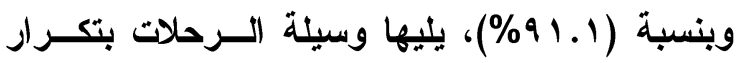
وللتعرف على الصعوبات التــي تحــول دون تكـوين وصناعة قيادات طلابية بالكلية، تم حساب التكــرارات

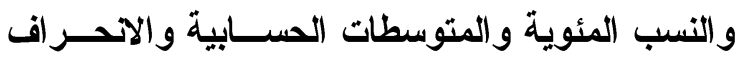

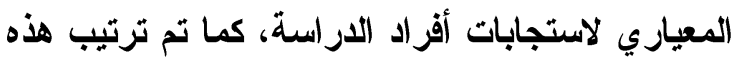
العبارات حسب المتوسط الحسابي لكلا منها، وذلك كما

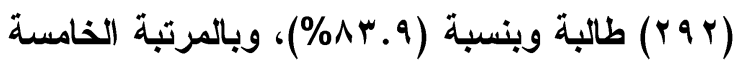

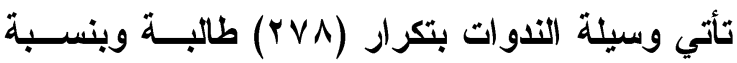
\% \% 9.9) الوسائل التي تساعد على تنمية وعي الطالبات بتكرار

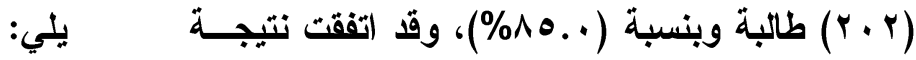
جدول رقم (V) يوضح الصعوبات التي تحول دون تكوين وصناعة قيادات طلابية بالكلية

\begin{tabular}{|c|c|c|c|c|c|c|c|c|c|c|}
\hline \multirow{3}{*}{$\begin{array}{l}i_{i} \\
E_{i} \\
E\end{array}$} & \multirow{3}{*}{ 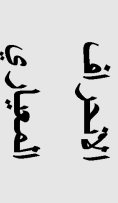 } & \multirow{3}{*}{$E$} & \multicolumn{6}{|c|}{ درجة المواققة } & \multirow{3}{*}{ العبار ات } & \multirow{3}{*}{ r } \\
\hline & & & \multicolumn{2}{|c|}{ ضعيفة } & \multicolumn{2}{|c|}{ متوسطة } & \multicolumn{2}{|c|}{ كبيرة } & & \\
\hline & & & $\%$ & ك & $\%$ & ك & $\%$ & ك & & \\
\hline 1 & $.0 \varepsilon$ & T.7ะ & r.r & $\wedge$ & r... & $v^{r}$ & V५.V & YTV & ضعف حماس الطالبات بسبب الضغوط & 1 \\
\hline
\end{tabular}


آلبات صناعة القبادات الطلابية لترسبخ مفامبه الوعي الفكري لدى

طالبات جامعة الأميرة نورة بنت عبد الرحمن من منظور الخدمة

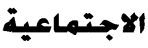

د. منال مشـبـ القحطبانع - د. نعمة البراهيم عوض

\begin{tabular}{|c|c|c|c|c|c|c|c|c|c|c|}
\hline \multirow{3}{*}{$\sum_{E}$} & \multirow{3}{*}{ 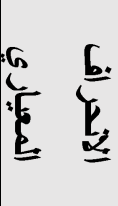 } & \multirow{3}{*}{$\underline{E}$} & \multicolumn{6}{|c|}{ درجة المواققة } & \multirow{3}{*}{ العبار ات } & \multirow{3}{*}{ p } \\
\hline & & & \multicolumn{2}{|c|}{ ضعيفة } & \multicolumn{2}{|c|}{ متوسطة } & \multicolumn{2}{|c|}{ كبيرة } & & \\
\hline & & & $\%$ & ك5 & $\%$ & ك & $\%$ & 5 & & \\
\hline & & & & & & & & & الأكاديمية & \\
\hline r &. $.7 \mathrm{~V}$ & T.rA & $1 . \varepsilon$ & 0 & ro.r & $\wedge \wedge$ & Vr.T & ros & اقتصار البرامج والأثثطة على ذوي & $\varepsilon$ \\
\hline$r$ &. .09 & T.rV & r.q & 1. & rV.r & 90 & 79.1 & $r \leqslant r$ & ضعف الوعي لاى البعض من الطالبات & $r$ \\
\hline$\varepsilon$ &. .41 & T.TE & r.. & v & ro.9 & 9. & VY.I & rol & عدم تواقر الاعم المادي لعمل البرامج & 0 \\
\hline 0 & .67 & r.. q & $1 . \varepsilon$ & 0 & rr.. & $\wedge$. & V0. & r4T & عدم توافر الأماكن المناسبة لإقامة & $r$ \\
\hline- & $\cdot . \varepsilon \varepsilon$ & T.rT & & & & & & ابي | & المتوسط الا & \\
\hline
\end{tabular}

بفوائل ممارسة الأشطة) بمتوسط حسـابي (r.rV) وباتحر اف معياري (هوه. ·) وبدرجة موافقة (كبيرة)، وتأتي العبارة رقم (0) والتي تنص على (عدم تـــوافر

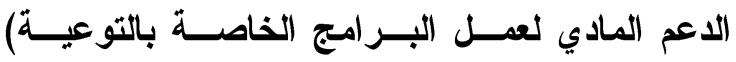

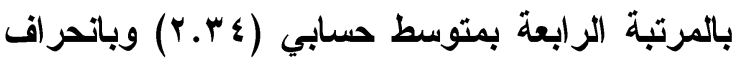

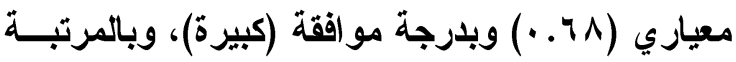

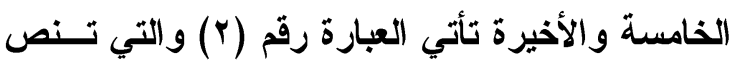

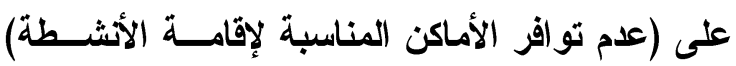

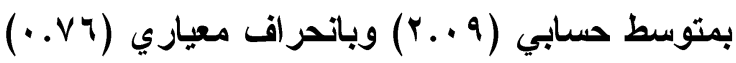
وبلرجة موافقة (متوسطة)، وقد اتفقت نتيجة الاراسة وبنة

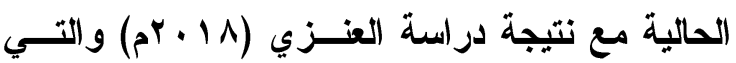

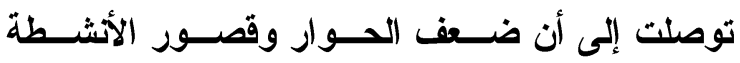
الجامعية من التحديات التي تواجه الجامعات في تعزيز مستوى الأمن الفكري لاى الطالبات، كما اتفقت نتيجة

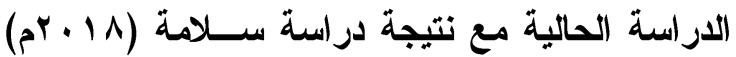

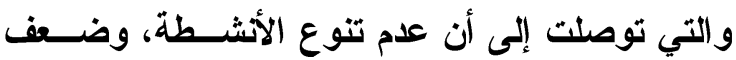

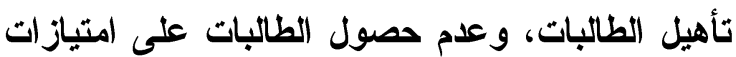
من المعوقات التي تحد من ممارسة الأشطة الطلابية

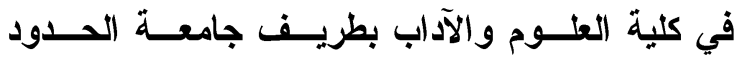
الثمالية، كما اتفقت نتيجة الاراسة الحالية مع نتيجة

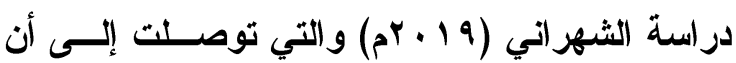

يتضح من الجدول رقم V) أن محور الصعوبات التي تحول دون تكوين وصناعة قيــادات طلابيــة بالكليــة يتضمن (0) عبارات، تراوحت المتوسطات الحســابية

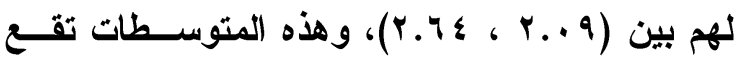
بالفئتين الثانية والثالثة من فئات المقيـاس المتــدرج الثلاثي، وتُشير النتيجة السابقة إلــى أن اســتجابات

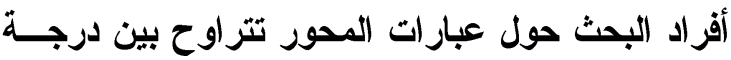
مو افقة (متوسطة إلى كبيرة).

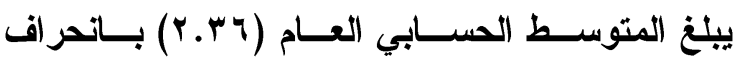

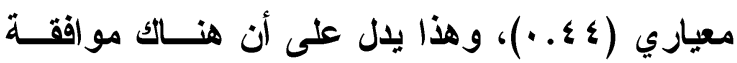
بلرجة كبيرة بين أفراد الدراسة على الصعوبات التــي لهي

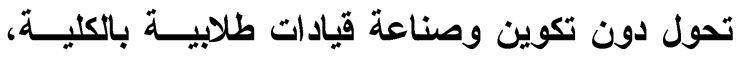

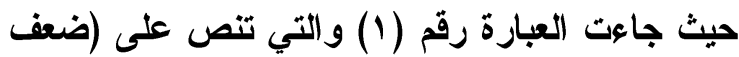
حماس الطالبات بسبب الضغوط الأكاديمية) بالمرتبــة عيـة

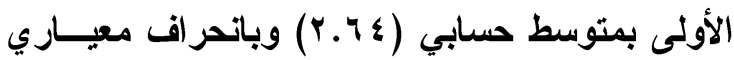

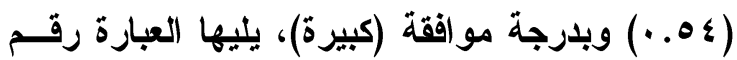

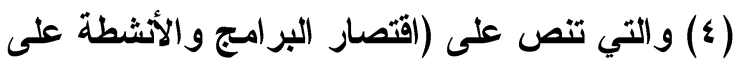
ذوي المهارات والخبرات الخاصة) بمتوسط حســابي (Y.r^) (كبيرة)، وبالمرتبة الثالثة تأتي العبارة رقم (ץ) والتي تنص على (ضعف الوعي لاى البعض من الطالبــات 
آلبات صناعة القبادات الطلابية لترسبخ مفاهبه الوعي الفكري لدى

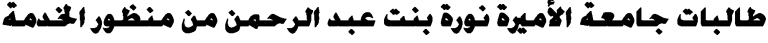

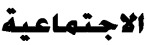

د. منال مشيب القحطاني - د. نعمة ابراهيم عوض

وللتعرف على مقترحات تفعيل الأشطة والتي تشـــاعد

على تنمية الوعي لاى الطالبات، تم حساب التكرارات

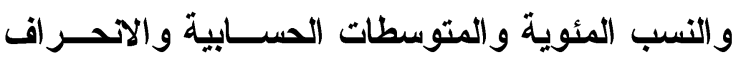

المعياري لاستجابات أفراد الاراسة، كما تم ترتيب هذه وابه

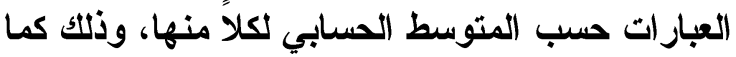

المجلة العلمية للخدمة الاجتماعية

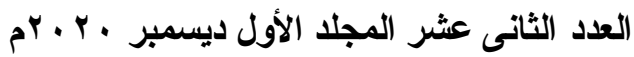

تعارض الأنشطة مع أوقات المحاضــرات ، وافتقــار الأنشطة الى الأساليب الإبداعية من التحديات التهات التي تحد

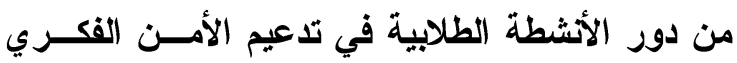
لطبة الجامعة. السؤال السادس: ما مقترحات تفعيل الأنشطة والتــي تُساعد على تنمية الوعي لاى الطالبات؟

جدول رقم (^) يوضح مقترحات تفعيل الأنشطة والتي تُساعد على تنمية الوعي لاى الطالبات

\begin{tabular}{|c|c|c|c|c|c|c|c|c|c|c|}
\hline \multirow{3}{*}{$E_{i}$} & \multirow{3}{*}{ 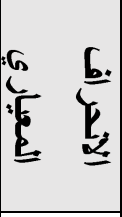 } & \multirow{3}{*}{$\underline{E}$} & \multicolumn{6}{|c|}{ درجة المواققة } & \multirow{3}{*}{ 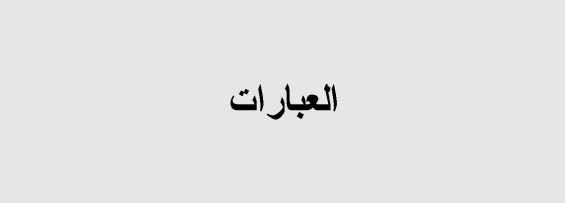 } & \\
\hline & & & \multicolumn{2}{|c|}{ ضعيفة } & \multicolumn{2}{|c|}{ متوسطة } & \multicolumn{2}{|c|}{ كبيرة } & & م \\
\hline & & & $\%$ & ك5 & $\%$ & ك & $\%$ & ك & & \\
\hline 1 &..$r \Lambda$ & Y.Ar &.$r$ & 1 & 17.8 & ov & Ar.r & rq. & توفير برامج متتوعة تساعد في & $r$ \\
\hline r & $\cdot \varepsilon$ & Y.AI & .7 & $r$ & IV.0 & 71 & $\wedge 1.9$ & rAo & وتح قنوات اتصال بين الطالبات & $\varepsilon$ \\
\hline$r$ & 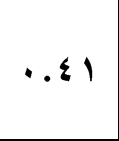 & r.^I & $\cdot .9$ & $r$ & IV.. & 09 & Ar.r & rAт & خلق فرص الحوار و المناقشات المختلفة & $v$ \\
\hline$\varepsilon$ & $\because \varepsilon r$ & r.^1 & 1.1 & $\varepsilon$ & IV.. & 09 & 11.9 & r^o & تبادل الخبرات محلياً وعالمياً. & $\wedge$ \\
\hline$\bullet$ & $\cdot . \varepsilon r$ & Y.V 9 & $\cdot .9$ & $r$ & $19 . r$ & TV & $\vee 9.9$ & rVA & توفير التوجيه والإثر اف المناسب لتنفيذ & r \\
\hline 7 & $\because \leqslant 0$ & r.VA & $1 . v$ & 7 & $1 \wedge .1$ & 84 & $\Lambda \cdot r$ & rVq & زيادة الدورات التدريبية لمرشدات & 0 \\
\hline v & 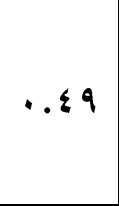 & r.Vo & r.q & $1 \cdot$ & $19 .$. & 97 & VA.r & TVY & 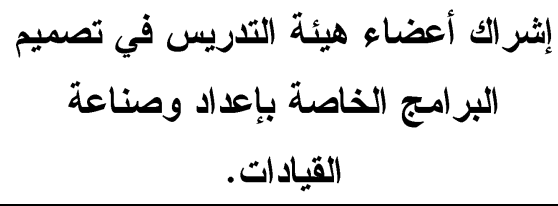 & 7 \\
\hline$\wedge$ &. .01 & r.Vo & r.r & $\wedge$ & $r \cdot . v$ & Vr & VV.. & ห५ & الاستعانة بالخريجات القياديات. & 9 \\
\hline 9 &. $.0 \wedge$ & r.74 & $0 . V$ & $r \cdot$ & r..l & VV & Vr.l & rol & عقد الاجتماعات و الندوات لتوعية & 1 \\
\hline- &..$r q$ & Y.VA & & & & & & 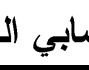 & المتوسط الد & \\
\hline
\end{tabular}

بالفئة الثالثة من فئات المقيــاس المتــــرج الثلاثــي، وتثثير النتيجة السابقة إلى أن استجابات أفراد البحث حول عبارات المحور جاعت بلرجة مواققة (كبيرة).
يتضح من الجدول رقم (^) أن محور مقترحات تفعيل الأشطة و التي تُساعد على تنمية الوعي لاى الطالبات يتضمن (9) عبارات، تراوحت المتوسطات الحســابية

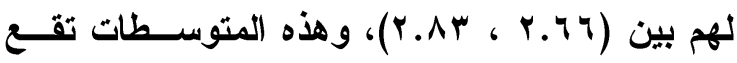


آلبات صناعة القبادات الطلابية لترسبخ مفاهبه الوعي الفكري لدى

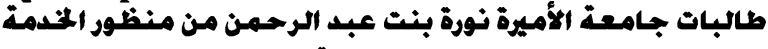
الاجتماعية

د. منال مشـبـ القحطبني - د. نعمة البراهيم عوض

العمل من المقترحات التي تُساهم في تعزيز الأنمـاط

القيادية لاى طلاب الجامعة.

توصيات ومقترحات الار اسة الدهاء

في ضوء النتائج التي تم التوصل إليها توصي الباحثة

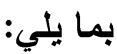

ا. تعزيز الأششطة (الثقافية - الفكرية - الفنبــة

- الصحية - الريفية) التي تقــدم للطالبــات التهاته والتي يمكن أن تُساعد في اكتشاف وصناعة

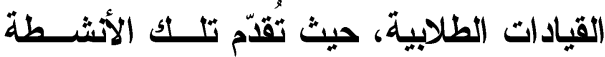

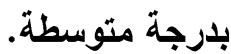

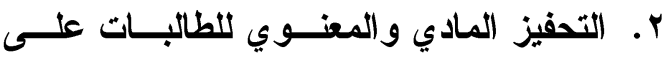

المشاركة في الأنشطة الطلابية.

r. إتاحة الفرصة لجميع الطالبات للمشاركة في الميطه

برامج وأنثطة تكوين وصــناعة القيـادات

الطلابيـــة، وعــــم اقتصـــــارها علـــى ذوي

المهار ات و الخبرات الخاصة.

ع. توعية الطالبات من خلال اللقاءات والندوات

المفتوحة بفو ائد ممارسة الأنشطة، ودورهــا لونسا

في إعداد القيادات الطلابية.

ه. الدورات التدريبية وورش العمل لمرشــات

النشاط بالجامعة، لتفعيل دورهم في المجتمع

الجامعي، وتفعيل الأنشطة التي من شأنها أن

تساهم في إعداد وتكوين القيادات الطلابية. ד. إجراء دراسة مماثلة تتناول آليات صــناعة

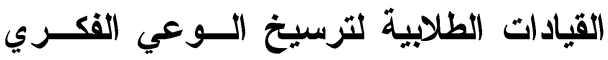
بكليات أخر ويجامعات أخرى.

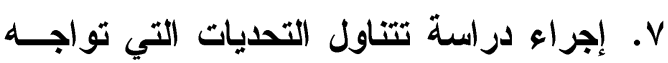

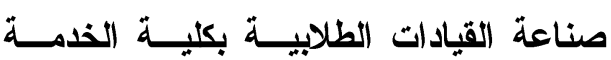

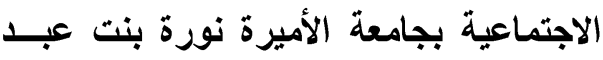

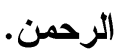

المجلة العلمية للخدمة الاجتماعية

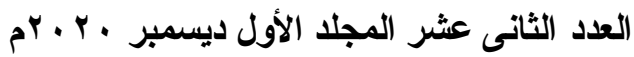

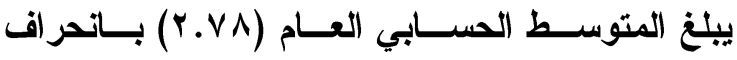

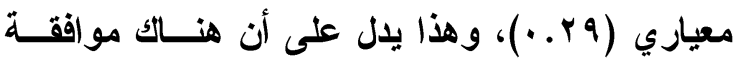

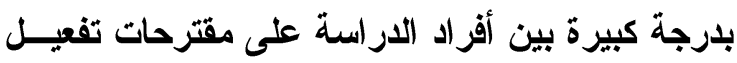

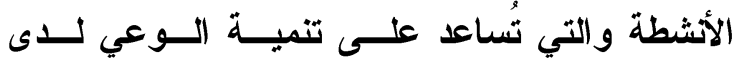

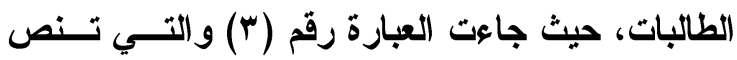

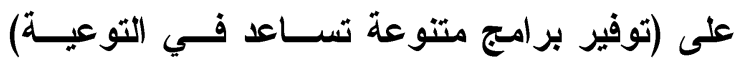

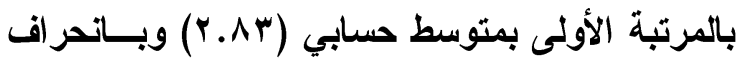

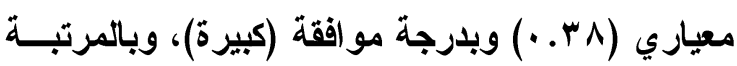

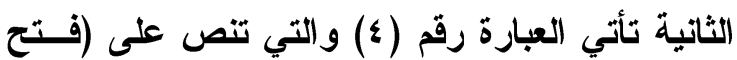

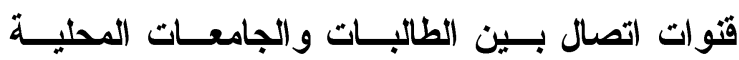

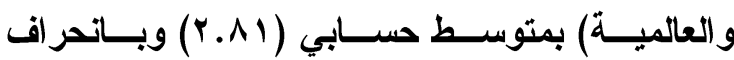
معياري (• ع . •) وبدرجة موافقة (كبيرة)، وبالمرتبـة

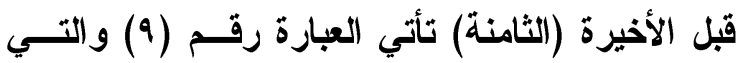
تنص على (الاستعانة بالخريجات القياديات) بمتوســ لاني

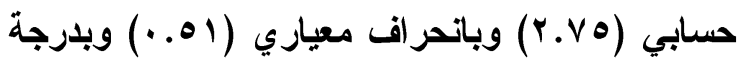

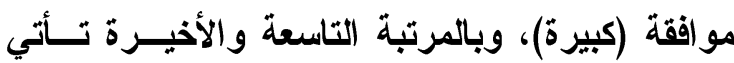
العبارة رقم (1) والتي تنص على (عقد الاجتماعــات

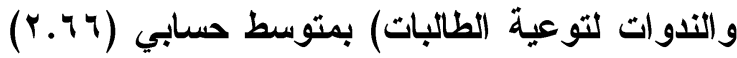
وباتحر اف معياري (^^ه. •) وبلرجة موافقة (كبيرة)،

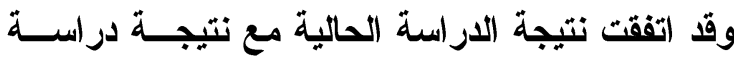

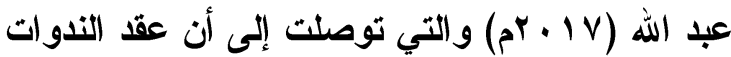
وورش العمل التي تضم كبــار المســـولين ورجــال التربية و الاين و السياسة والاجتماع والإعلام للتعريف بالأمن الفكري وأهميته وكيفية تحقيقه، إضــافة إلــى ولــ

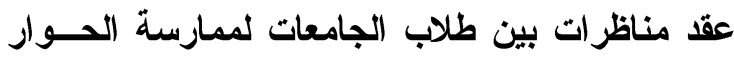
ونبذ التعصب الفكري من المقترحات التي تُساهم فــي لئي تعزيز الأمن الفكري لاى الطلاب بالجامعات المصرية،

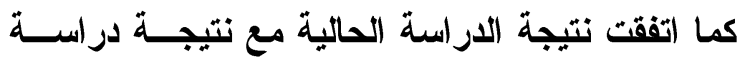

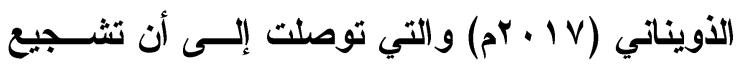
تبادل الخبرات بين الجامعات وتفعيل الأشطة الطلابية

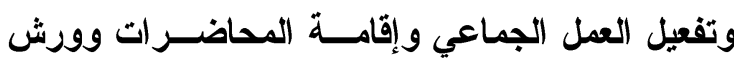


مقترح إطار تصوري لاور الخدمة الاجتماعية في كيفية صناعة القيادات الطلابية

$$
\text { لترسيخ مفاهيم الوعي الفكري }
$$

بجامعة الأميرة نورة بنت عبد الرحمن - كلية الخدمة الاجتماعية

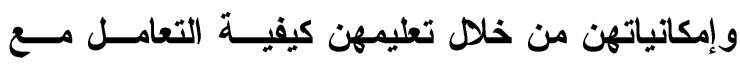
الصعوبات والمعوقات التي تحول دون مشاركتهن في

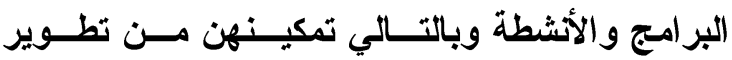
قدر اتهن ومهار اتهن القيادية.

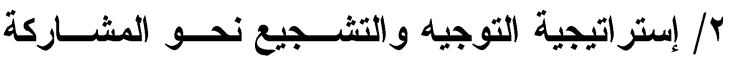
المجتمعية. r/ إستراتيجية التعديل البيئي، وذلك لإحداث تغيــرات في البيئة الجامعية.

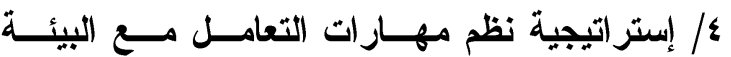
الاجتماعية وتتضمن تدريب الطالبات على المهــارات الاجتماعية التي يكتسبها من خلال عملية الاضـطلاع

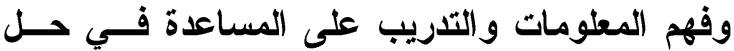
المشكلات. • إستر اتيجية التضامن ويتم ذلكك من خلال التعبـين بين أعضاء الهيئة التعليمية والأخصائيات الاجتماعيات ومشرفات النشاط. التكنيكات المستخدمة: / الدورات التدريبية:

وتكون بعد مرحلة اكتثاف الســـات القياديــة لـــى لــ

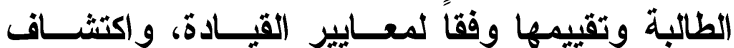
جوانب القصور والتميز و التفاوت في القدرات، ومسن

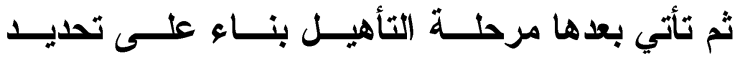
الاحتياجات التدريبية ثم مرحلة التكاليف (التجربة) ثم ثمانية

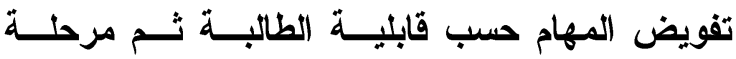

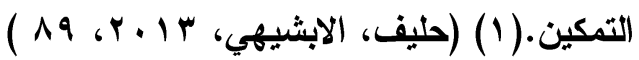

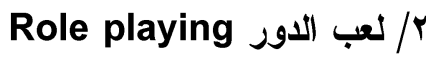
عبارة عن أسلوب تدريبي يسمح للطالبــة بممارســة

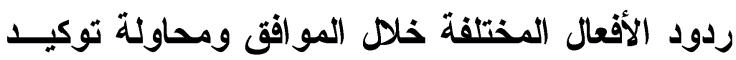
الواقع بهذه الطريقة يؤدي إلــى اســتبعاد المخــاطر

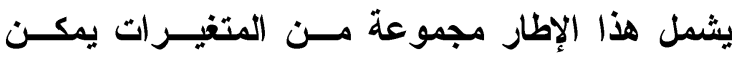
عرضها فيما يلي: الهلف العام: مقترح لتدريب الطالبات ذوات القـــرات و المهار ات المتميزة لتأسيس قيادات طلابية بالجامعسة لترسيخ مفاهيم الوعي الفكري. الأهد اف التفصيلية:

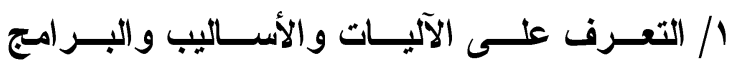

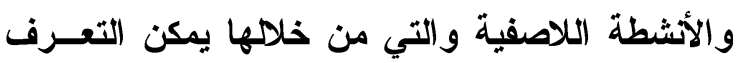
على الطالبات ذوات الاستعدادات القيادية. r / تدريب الطالبات ذوات الأستعداد القيادية. r/ إيجاد حلول للصعوبات و المعوقات التي تحد مسن دور الطالبات القيادات. ع / مشاركة الطالبات القياديات في الأشطة المصاحبة لترسيخ مفاهيم الوعي الفكري.

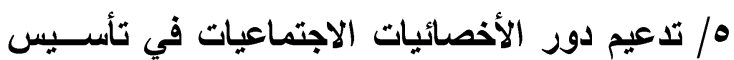
وصناعة القيادات الطلابية. 4/ تحديد أدوار واضحة للأخصائيات فـــ ممارســة الأنشطة لبناء وتأسيس قيادات طلابية.

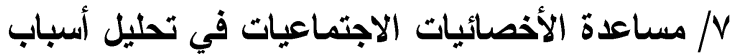
الصعوبات التي تواجهها جماعات النشاط الطلابي. الأسس التي يقوم عليها الإطار التطوري: يستند الإطار التصور المقترح على ما يلي: 1 - نتائج الار اسة الميدانيــة الحاليــة و الار اســـات و السابقة التي أجريت. r - الإطار النظري للخدمة الاجتماعية وطريقة العمل مع الجماعات بصفة خاصة في مجال القيادة، بالإضافة إلى الأساس المعرفي لممارسة الخدمــة الاجتماعيــة فئة

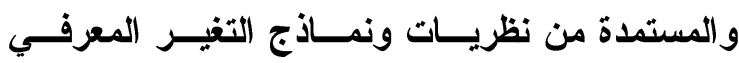
ونظرية التعلم الاجتماعي ونظرية التعديل السلوكي. الاستر اتيجيات المهنية المستخدمة:

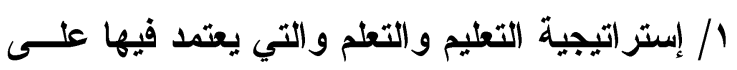

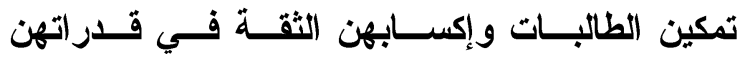




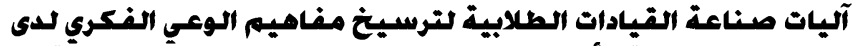

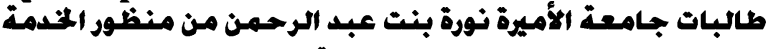
الاجتماعية

د. منال مشـبـ القحطبني - د. نعمة ابراهيم عوض

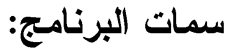

/ المرونة، يراعي الفروق الفرديــة ويتكيـف مـــع

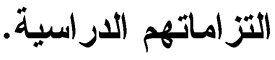

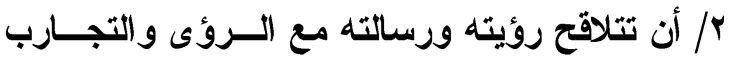

القيادية العالمية والعربية والمحلية.

r/ الشمولية: أن يتمسك على المكونـــات المعرفيــة والمهارية (صقل مهار ات القيادية) والقيمية والتنموية لائه

(تنمية الاتجاهات)، الإباع، الابتكار، التفرد.

ع / البر امج والأشطة و الفعاليات و المبادرات.

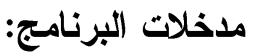

باعتبار أن هذا البرنامج موجه نـو تأسيس القيـادات الطلابية، فلابد من مجموعة مدخلات منها:

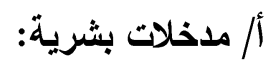

- وهي التي تتم من خلال اكتشاف الطالبــات

ذوي الاستعدادات و القدرات القيادية، الالتزام

الخظقي.

- توظيف الكـــوادر القياديــة المتميــزة مــن

الطالبات حتى يمكنهن التأثير والتغير فـي

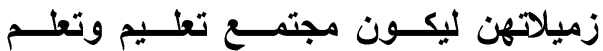

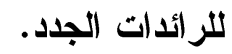

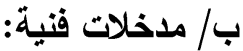

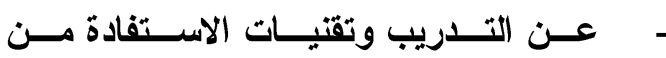

الإمكاتيات المتاحة بالإضافة إلى متطلبـات

و استر اتيجياتها للتطبيق.

ج/ مدخلات ثقافية:

- من الثقافــة التنظيميــة للعمـلـل القيــادي،

والتعايش القيادي ميع فريث العمل القيــادي

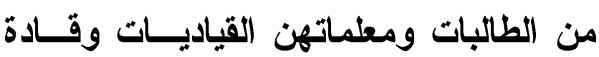

المجتمع المــؤثرين والقيــادات الطلابيــة

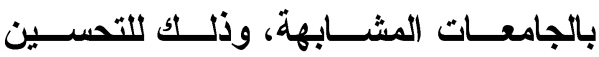

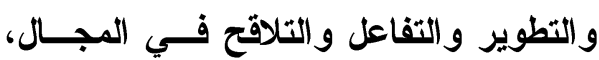

وجدوى التذريب، بالإضــافة إلــى التبــادل

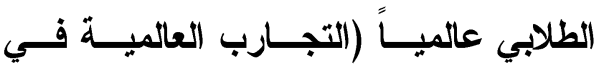

(القيادة).

د/ مدخلات إدارية وقانونية:
المجلة العلمية للخدمة الاجتماعية

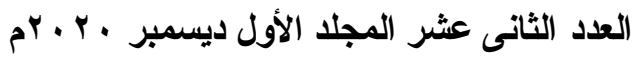

ويعمل على نشر الأفكار والممارسة القيادية من خلا

النماذج التطبيقية.

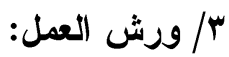

لابد من تحديد خصائص ملامح معينة للورشة. \& / العصف الأهني:

وهو أسلوب لإنتاج الأفكار الجديدة والإبــــاع ويعـــل

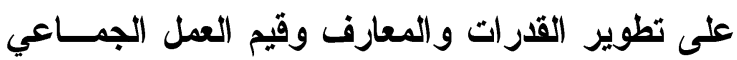
و المهار ات القيادية.

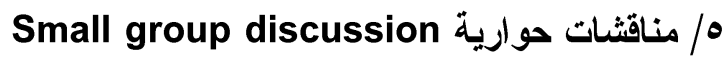
وتعني بتبادل الأفكار والآراء وجهاً لوجه. 4/ الرحلات و المعسكرات الصيفية: وتتمكن الطالبة فيها من إبراز وتنمية مهار اتها مسن

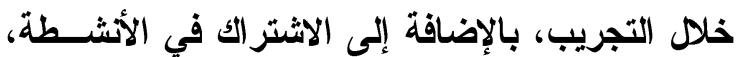
الاشتترالك في الإعلام المرئي والمســموع و الزيــارات الخارجية التعليمية (برنامـج التبــادل الطلابــي داخــل

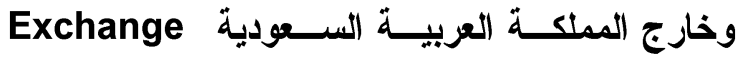
(student programms

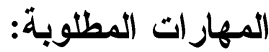
تتضمن كل المهارات الخاصة بالقيادة وبــث الــوعي الفكري، وتضم كمثال لذلك:

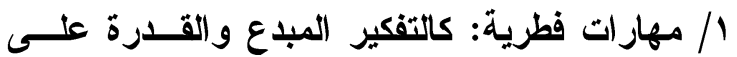
التصور كالذكاء الاجتماعي. r/ مهارات إنسانية: اجتماعية كالعلاقات الاجتماعيــة

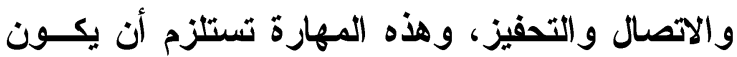
القائد قدرة حسنة في تصرفاته وسلوكهه. / / مهارات فنية تخصصية: كالقدرة على المســـاعدة في حل المشكلات واتخاذ القرارات،(حليف، الابشيهي، ( AV G T I I

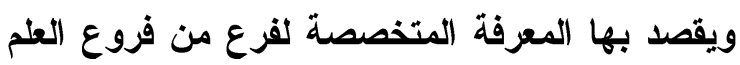

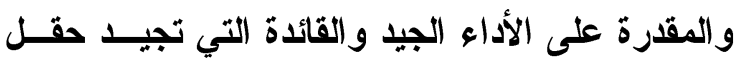

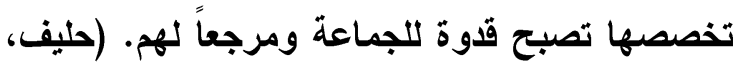

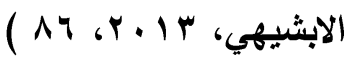
\& / مهار ات التوجيه و الاتصال و التفاعل.

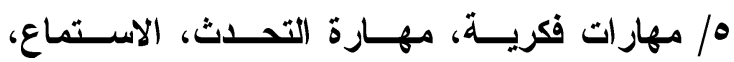
المواجهة، الملاحظة، الاتصال بناء العلاقات. 


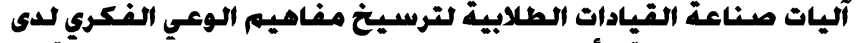

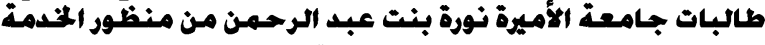
الاجنماعية

د. منال مشـبـ القحطبني - د. نعمة البراهيم عوض

- نشر ثقافة التطوع وخدمة المجتمع وسـط

$$
\text { الطالبات و التحفيز . الدعز }
$$

-

التعليمية والتشجيع وتبني الأفكار القيادية.

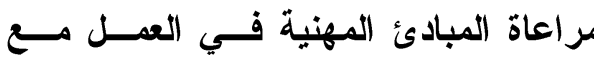

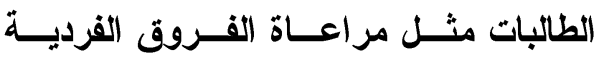

و التفاعل الجماعي و التحفيز مــع جماعــات

(النشاط.

الاستعانة بالخبر اء والقياديات فــي مجــال

القيادة و التبادل الطلابي خارجياً.

-

$$
\text { عمل فريقي يضم: }
$$

/ / مشرفات النشاط الطلابي.

r/ الأخصائيات الاجتماعيات.

r/ أعضاء الهيئة التعليمية.

ع القياديات من الهيئة التعليمية.

• / الطالبات أنفسهن.

؟/ الإداريات و الموظفات بالكلية.
المجلة العلمية للخدمة الاجتماعية

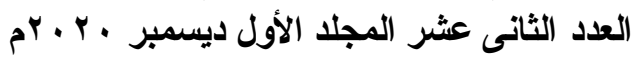

- لوائح ونظم العمل للطالبة بما في ذلك ميثاق

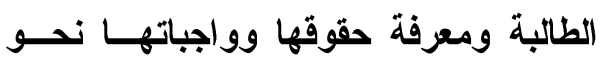

مجتمعها.

هـ/ مدخلات اقتصادية:

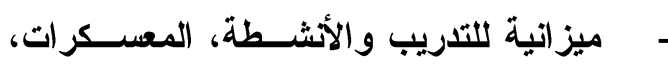

الزيارات، التبادل الطلابي عالمياً.

مخرجات البرنامج:

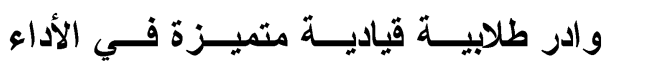

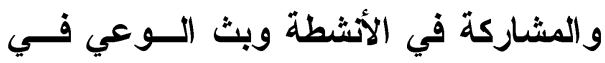

البيئة الجامعية.

- كوادر طلابية قيادية قــادرة علــى التـأثير

و التغيير في محيط الجامعة و المجتمع خاصة

فيما يتعلق بالقيادة كقدوة.

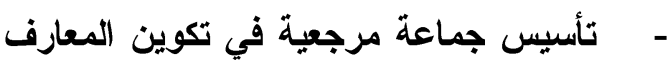

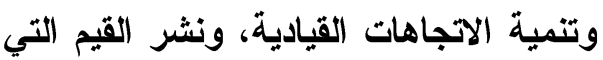

تعالج الكثيـر مــن المشـكـلات الســلوكية

و الاجتماعية و النفسية.

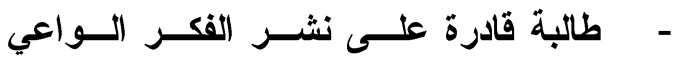

و الممارسة القيادية الرشيدة وذلك من خلال

النسق القيمي والقدوة الحسنة في المجتمع.

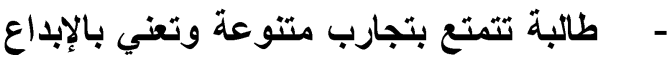

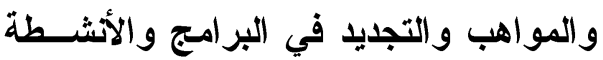

و الفعاليات المحلية و العالمية.

- طالبة قادرة على تمثيل جامعتهـــا خارجيـاً

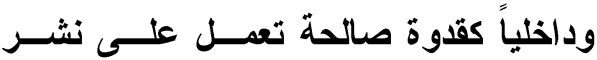

الثقافة المجتمعية.

الفترة الزمنية:

برنامج يتسم بالاستمر ارية، يبدأ منذ دخــول الطالبــة

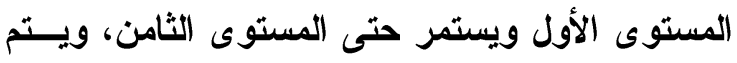

التتفيذ أثناء الفترة الار اسية (تفصل الآلية التــي يــتم

بها وفقاً للمرحلة و المستوى الخاص بالطالبة).

عو امل نجاح التصور المقترح: / / مساندة الكلية ودعمها للبرنامج:

- - لاعم الفكري والمعنوي.

- 


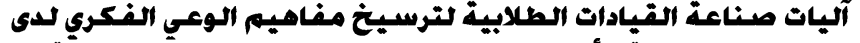

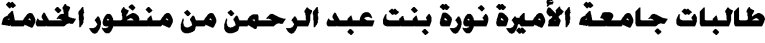
الاجتماعية

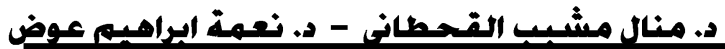

• 1 . سلوى عثمان الصديقي وآخــرون،

منهاج الخدمــة الاجتماعيــة فــي المجــال

المدرسي ورعاية الثباب، المكتب الجــامعي

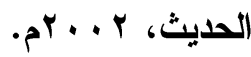

عاطف خليفة محمد، العلاقة بـين

مشاركة في الأسر الطلابية وتنمية المسئولية

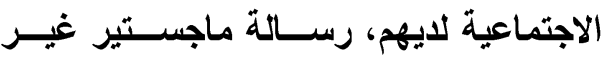

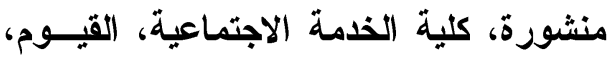
$.0199 \mathrm{~V}$

عبدالله احمد سالم الزهراني ، بناء

برامج القيادات الطلابية لتنمية بعض القـيم

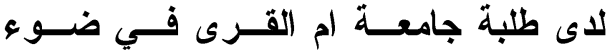
الاتجاهات العالمية المعاصرة ، كلية التربية ,

جامعة ام القزى ، مكة المكرمة, 9 ا ـ ז. با. عفاف محمد عبد المنعم، نحو دور

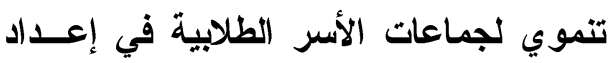

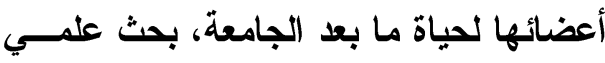

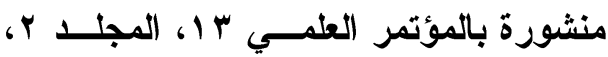

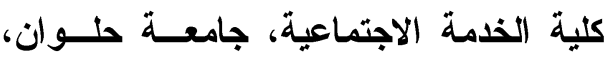

$$
\text { . }
$$

ع 1 . فؤاد البكري، دور الاتصال المباثر

في تنمية الوعي الاجتماعي، رسالة دكتوراه غير منشورة، كلية الإعلام، جامعة القاهرة.

10 كرم محمد أحمد الجندي، العلاقـــة

بين قيام الأخصائي الاجتماعي بأعمال الريادة

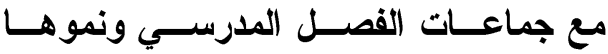
الاجتماعي، رسالة دكتوراه غير منشــورة،

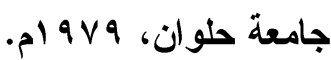

ماهر أبو المعاطي، إطار تصــوري

مقترح لتظوير رعاية الثباب الجامعي، بحث منشــور، مجلـــة الدراســـات فــي الخدمــة الاجتماعية والعلوم الإنسانية، كلية الخدمسـة الاجتماعية، حلوان،
المجلة العلمية للخدمة الاجتماعية

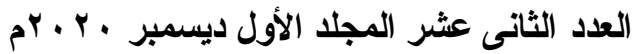

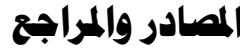

المراجع العربية:

ا ـ ابتسام خالد ســلامة , معوقــات ممارســة

الأششطة الطلابية في كليــة العلــوم والآداب

بطريف جامعة الدودد الثمالية من وجهــة

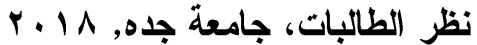

r ـ إبراهيم الفقي، سحر القيادة: كيـف تصــبح

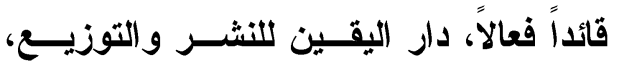

$$
\text { المنصورة. }
$$

r. إبراهيم مدكور، معجم العـــوم الاجتماعيـة، الهيئة المصرية العامة للكتــاب، القــاهرة،

$$
\text { .p } 9 \text { V }
$$

ع. أحمد زكي بلدوي، معجم مصطلحات العـــوم

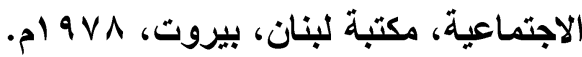

ه. أحمد محمد يوسف عليق، أحمد عبد الحميا

الأبثــــبي، القيــادة وتنمبــة المجتمعـــات

المحلية، مكتبة المتتبئ، الـــمام، المملكــة

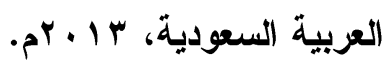

7. الحسينة، سليم، نظم المعلومــات الإداريــة،

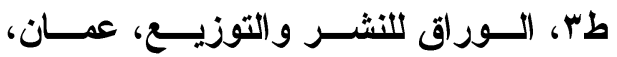

$$
\text { . }
$$

V. آمال بدر عبد الثافعي، اســتخدام أســاليب

التنظـيم الـــوظيفي فـــي خدمــة الجماعـــة

وسلامتها باكتساب السلوك القيادي، رســالة

ماجستير غير منشورة، جامعة حلوان، كلية

الخدمة الاجتماعية، ب 99 ام.

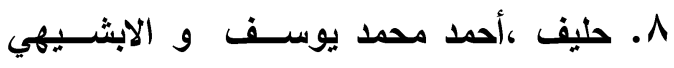

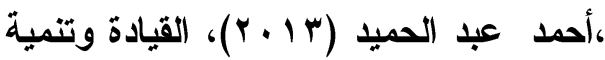
المجتمعات المحلية، مكتبة المتتبئ، الــدمام، المكلة العربية السعودية.

9 ـ زكي، داليـا، الــوعي الســياحي و التنميـة

السياحية مفاهيم وقضايا، مؤسســة شــباب

$$
\text { الجامعة، الإسكندرية، } 1 \text { ـ . ب rم. }
$$




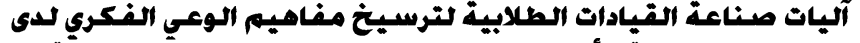

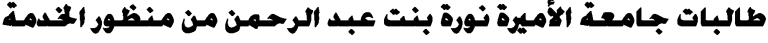
الاجتماعية

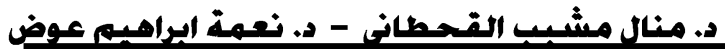

منشور بالمؤتمر العلمي ه، كليــة الخذمــة

الاجتماعية، جامعة حلوان، الو 991 ام.

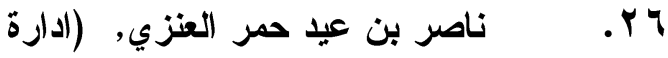

الأشطة الجامعية ودورها في تعزيز الأمسن

الفكري رسالة (ماجسـتير)-جامعسة نـايف

العربيــة للعلـــوم الأمنيــة، كليـــة العلـــوم

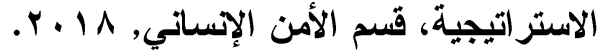

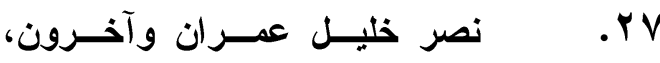

الخدمة الاجتماعية في مجال رعاية الشباب،

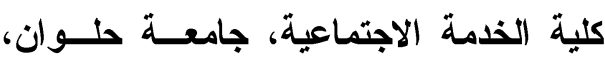

$.0199 V$

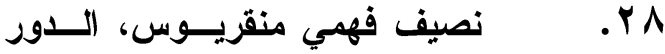

المقترح لطريقة خدمة الجماعة فــي تنميـة

اتجاه الشباب نحو المشاركة في المشروعات

الإتتاجية الجماعية، بحــث علمـي منثــور

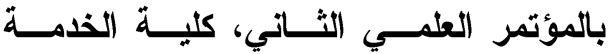

الاجتماعية، جامعة القاهرة، فــرع القيــوم،

.0199.

نورة الاعجاني ،مساهمة الأنشطة

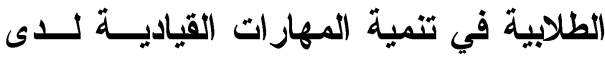

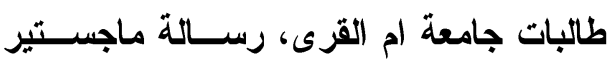

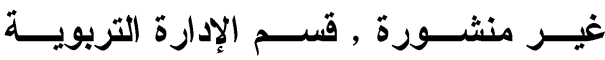

و التخطيط ، جامعة ام القرى , امكة المكرمة

$r \cdot 17$

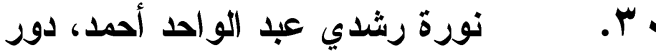

الخدمة الاجتماعيــة فــي تنميــة القبــادات

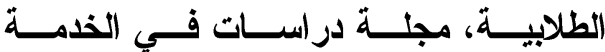

الاجتماعية والعلوم الإنسانية، مصر، أكتوبر

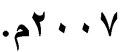

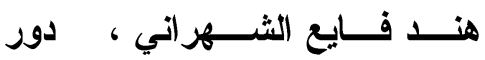

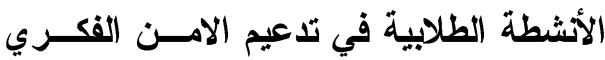

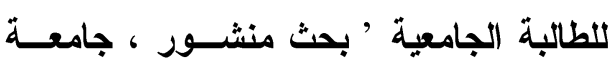

نايف العربية للعلوم الأمنية. 9 1 ـ r.
المجلة العلمية للخدمة الاجتماعية

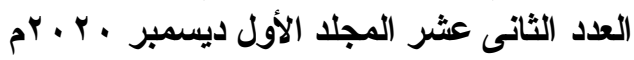

IV

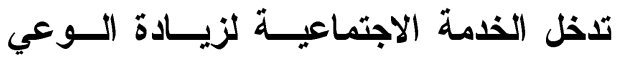

التنموي بين طلاب الجامعة، رسالة دكتوراه

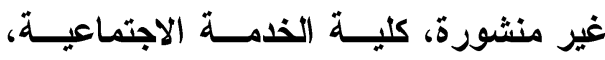
جامعة القاهرة، الفيوم، . . . ب م.

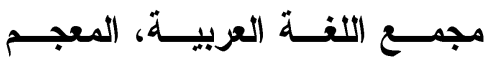
.11

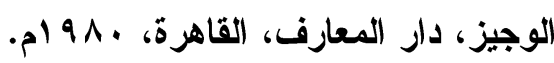

محمد أحمـــ عبـــ الــرحيم، دور

الخدمة الاجتماعية في زيادة وعـي أهـالي منطقة حضرية متخلقة بالمشكلة الســكانية، رسالة ماجستير غير منشورة، كلية الخدمة الاجتماعية، جامعة حلوان، الفيوم، 9919 ام. • . . . محمد سـيد فهــــ المتطلبـات المهارية للعاملين مع الثباب لتحقيق التنمية

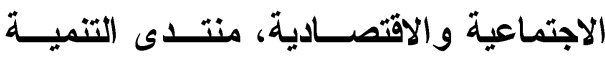

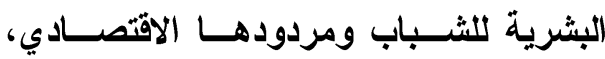

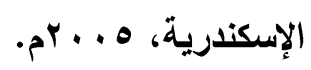

محمد فتحي محمد أبو عيسي، دور

الأخصائي الاجتماعي في التخطــيط لتنمبـــة

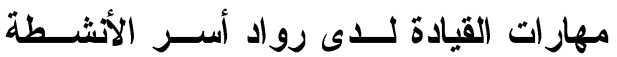

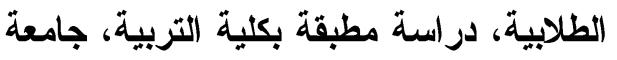

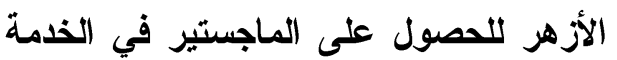

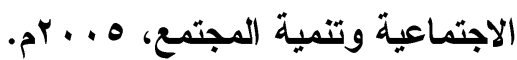

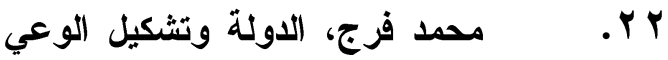

الاجتماعي في الاور الأيـــيولوجي للاوبـــة:

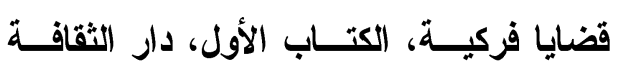
الجديدة، القاهرة، ه19 ام.

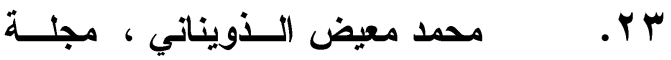

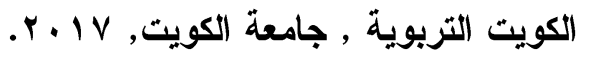

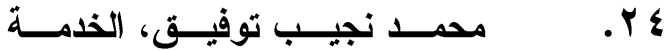

الاجتماعية في مجال رعاية الثباب، مكتبــة

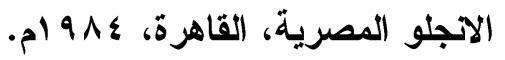

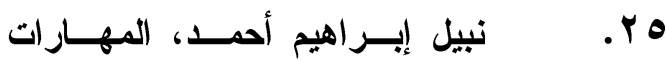
القيادية لروح الأسر الطلابية، بحث علمــي 
Ophysiology 89 (1): 525 - 533 . doi: 10: 1152/ in 00048: 2002.

Thoran Bawden, The role of .^ youth center in our modern life,

University of Ohio, 2005.

Vanrent Androw, Modern .9 political ideology, London,

Macmillan press, 1998, p. 22.

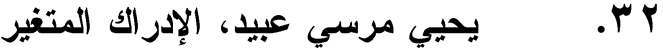

للشباب المصري، البطــاش ســنتر للنشــر

و التوزيع، الإسكندرية، 991 ام.

المراجع الأجنيبة: ولتونية.

Awad, M.E. and Ghaziri M. H, .I

Knowledge management, New

Jersey, Prentice Hall Upper

Saddle Revere, 2004.

Victoria Neufeld, New world .1. dictionary, New York, Prentice

Hall, 1994, p. 296.

Baulder press, 2006, p. 137.

Benjamin Bwolman, Dictionary .r

of behaviors science, New

Jeresy, printic Aa, 1993, p. 35.

Estell B. Freeman, Small group

psychology consciousness

raising in comparative times,

New York, Rutledge press,

1999, p. 39.

Estell B. Freeman, Small group .o psychology consciousness raising in comparative times, New York, Rutledge press, 1999, p. 121.

Sauge Franreli, The individual . conscious Ineer precrr, New York, Rutledge press, 2001, p.

45.

Smith Androw T., Surround .V

singh krishhna D, Williams drianl modulation measured with functional MRO in human visual context, Journal of New 